OECD Economics Department Working Papers No. 1305

\title{
Enhancing private \\ investment \\ in the Netherlands
}

Sanne Zwart 
Organisation de Coopération et de Développement Économiques

Organisation for Economic Co-operation and Development

20-Jun-2016

ECONOMICS DEPARTMENT

English - Or. English

\section{ENHANCING PRIVATE INVESTMENT IN THE NETHERLANDS}

ECONOMICS DEPARTMENT WORKING PAPERS No. 1305

By Sanne Zwart

OECD Working Papers should not be reported as representing the official views of the OECD or of its member countries. The opinions expressed and arguments employed are those of the author(s).

Authorised for publication by Robert Ford, Deputy Director, Country Studies Branch, Economics Department.

All Economics Department Working Papers are available at www.oecd.org/eco/workingpapers

JT03398431

Complete document available on OLIS in its original format

This document and any map included herein are without prejudice to the status of or sovereignty over any territory, to the delimitation of international frontiers and boundaries and to the name of any territory, city or area. 
OECD Working Papers should not be reported as representing the official views of the OECD or of its member countries. The opinions expressed and arguments employed are those of the author.

Working Papers describe preliminary results or research in progress by the author(s) and are published to stimulate discussion on a broad range of issues on which the OECD works.

Comments on Working Papers are welcomed, and may be sent to OECD Economics Department, 2 rue André Pascal, 75775 Paris Cedex 16, France, or by e-mail to eco.contact@oecd.org.

All Economics Department Working Papers are available at www.oecd.org/eco/workingpapers.

This document and any map included herein are without prejudice to the status of or sovereignty over any territory, to the delimitation of international frontiers and boundaries and to the name of any territory, city or area.

The statistical data for Israel are supplied by and under the responsibility of the relevant Israeli authorities. The use of such data by the OECD is without prejudice to the status of the Golan Heights, East Jerusalem and Israeli settlements in the West Bank under the terms of international law.

\section{(C) OECD (2016)}

You can copy, download or print OECD content for your own use, and you can include excerpts from OECD publications, databases and multimedia products in your own documents, presentations, blogs, websites and teaching materials, provided that suitable acknowledgment of OECD as source and copyright owner is given. All requests for commercial use and translation rights should be submitted to rights@oecd.org 


\section{ABSTRACT/RÉSUMÉ \\ Enhancing private investment in the Netherlands}

Investment has rebounded during the recent economic revival, but from a low level. The investment slump during the crisis was mostly caused by a fall in residential investment. However, business investment has been trending downwards since 1990, holding back capital stock accumulation and productivity. Raising residential investment is necessary to meet the growing demand, and in particular more private rental housing is needed as the current small stock, which reflects rental regulation and other housing policies, hampers the functioning of the housing market. Financing of owner-occupied housing can be made more resilient by stepping up measures taken after the crisis. Regarding business investment, further reinforcing the already good framework conditions would help to turn its cyclical upswing into a durably higher level. Meeting targets on R\&D expenditure and renewable energy requires lifting investments in the related areas. Financing conditions, which are widely perceived as an important bottleneck, could be improved by stimulating competition in the banking sector and the development of alternative financing sources.

This Working Paper relates to the 2016 OECD Economic Survey of the Netherlands (www.oecd.org/eco/surveys/economic-survey-netherlands.htm)

JEL classification codes: E22, G21, G23, O38, Q01, R31

Keywords: Investment, housing market, research \& development, sustainable development, SME financing.

$$
* * * * * * * *
$$

\section{Stimuler l'investissement privé aux Pays-Bas}

L'investissement s'est redressé depuis la reprise économique récente, mais à partir d'un niveau faible. La forte diminution observée pendant la crise était principalement imputable à la chute de l'investissement résidentiel. Cependant, l'investissement productif est orienté à la baisse depuis 1990, pesant sur l'accumulation du stock de capital et sur la productivité. Il est nécessaire d'accroître l'investissement résidentiel pour faire face à la demande croissante ; en particulier, il faut développer le parc locatif privé car le stock actuel, dont le niveau reflète l'encadrement des loyers et d'autres mesures en matière de logement, n'est pas favorable à un bon fonctionnement du marché immobilier. Étoffer les mesures prises après la crise pourrait permettre d'accroître la robustesse du financement des logements occupés par leurs propriétaires. Pour ce qui est de l'investissement des entreprises, continuer de renforcer les conditions cadres, déjà satisfaisantes, pourrait contribuer à transformer le redressement cyclique en amélioration durable. Atteindre les objectifs en matière de dépenses de R-D et d'énergies renouvelables nécessitera d'accroître les investissements dans les domaines concernés. Les conditions de financement, largement perçues comme un obstacle de taille, pourraient être améliorées par des mesures visant à stimuler la concurrence dans le secteur bancaire et par le développement d'autres sources de financement.

Ce Document de travail se rapporte à l'Étude économique de l'OCDE des Pays-Bas 2016 (www.oecd.org/fr/eco/etudes/etude-economique-pays-bas.htm)

Classification JEL: E22, G21, G23, O38, Q01, R31

Mots clef: Investissement, marché du logement, recherche et développement, développement durable, financement des PME. 


\section{TABLE OF CONTENTS}

ENHANCING PRIVATE INVESTMENT IN THE NETHERLANDS .....................................................

The slump in residential investment is accompanied by long-term challenges for business investment ....5

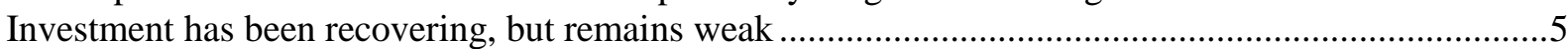

Bolstering private investment to support the housing market and boost growth potential ....................8

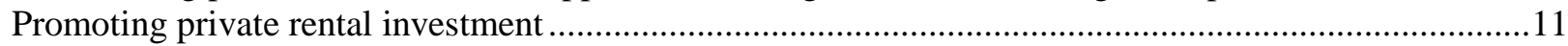

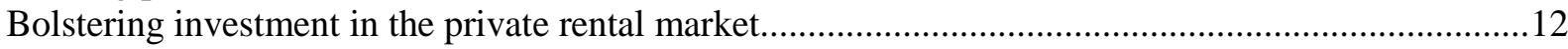

Safeguarding sustainable residential investment to maintain an adequate housing stock .....................13

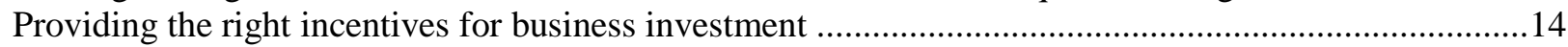

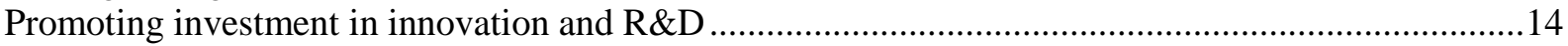

Supporting investments of start-ups and SMEs with growth ambitions .............................................16

Stepping up investment in clean energy and green growth .............................................................17

Further strengthening framework conditions for business investment..............................................18

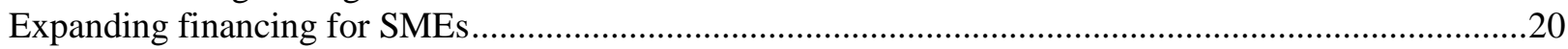

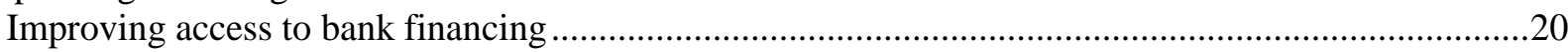

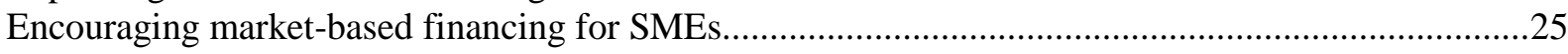

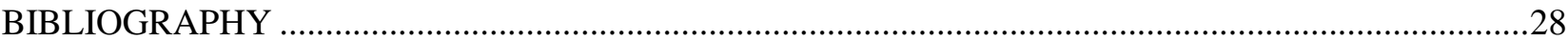

\section{Tables}

1. A wide range of alternative financing complements bank lending ............................................25

\section{Figures}

1. Investment had already been weakening before it was hit by the crisis ...........................................5

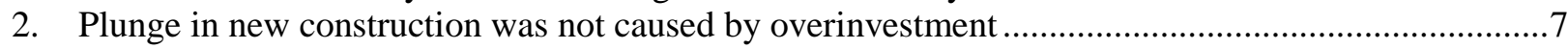

3. Lower capital-per-worker growth weighed on trend productivity .................................................. 8

4. Gap between non-residential investment needs and actual investment is substantial ........................9

5. Lower investment by business services has driven the decline in investment intensity .....................10

6. Investment in ICT equipment has grown fast, but investment in intangibles has stalled ...................11

7. Household spending on housing has increased, but remains moderate ............................................12

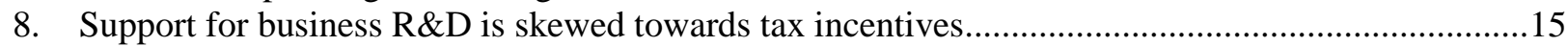

9. SMEs and large firms each account for half of business investment ...............................................16

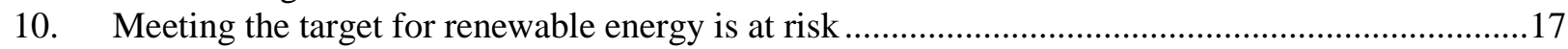

11. Infrastructure budget has been almost fully allocated until 2028 ............................................19

12. Corporate profitability has fallen and growth in corporate savings has stopped ..........................20

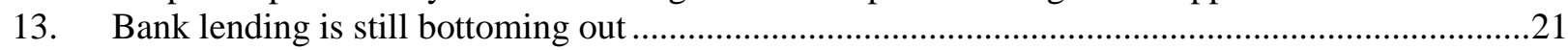

14. Bank lending constraints for small and medium-sized enterprises (SMEs) remain high................22

15. Public programs supported SMEs' access to credit during the crisis and beyond ........................23

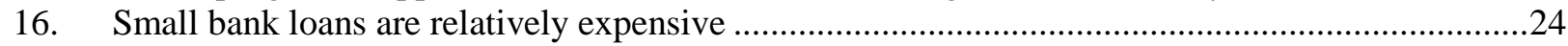

\section{Boxes}

Box 1. A wide range of public support programmes help companies obtain financing ..........................23

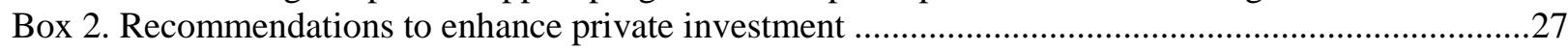




\title{
ENHANCING PRIVATE INVESTMENT IN THE NETHERLANDS
}

\author{
By Sanne Zwart ${ }^{1}$
}

\section{The slump in residential investment is accompanied by long-term challenges for business investment}

\section{Investment has been recovering, but remains weak}

Investment was hit hard by the recent crisis, but had already been weakening before. Until 2007, investment had been growing broadly in line with the overall economy (Figure 1, Panel A), but fell by almost $20 \%$ between 2008 and 2013, much more than the decline in gross domestic product (GDP). A similar contraction occurred in other advanced countries that simultaneously experienced subdued aggregate demand and a weak housing market (CPB, 2015a; IMF, 2015a; OECD, 2015a). Following the economic recovery in 2014, investment has started to strengthen, although it is still low relative to GDP.

Figure 1. Investment had already been weakening before it was hit by the crisis

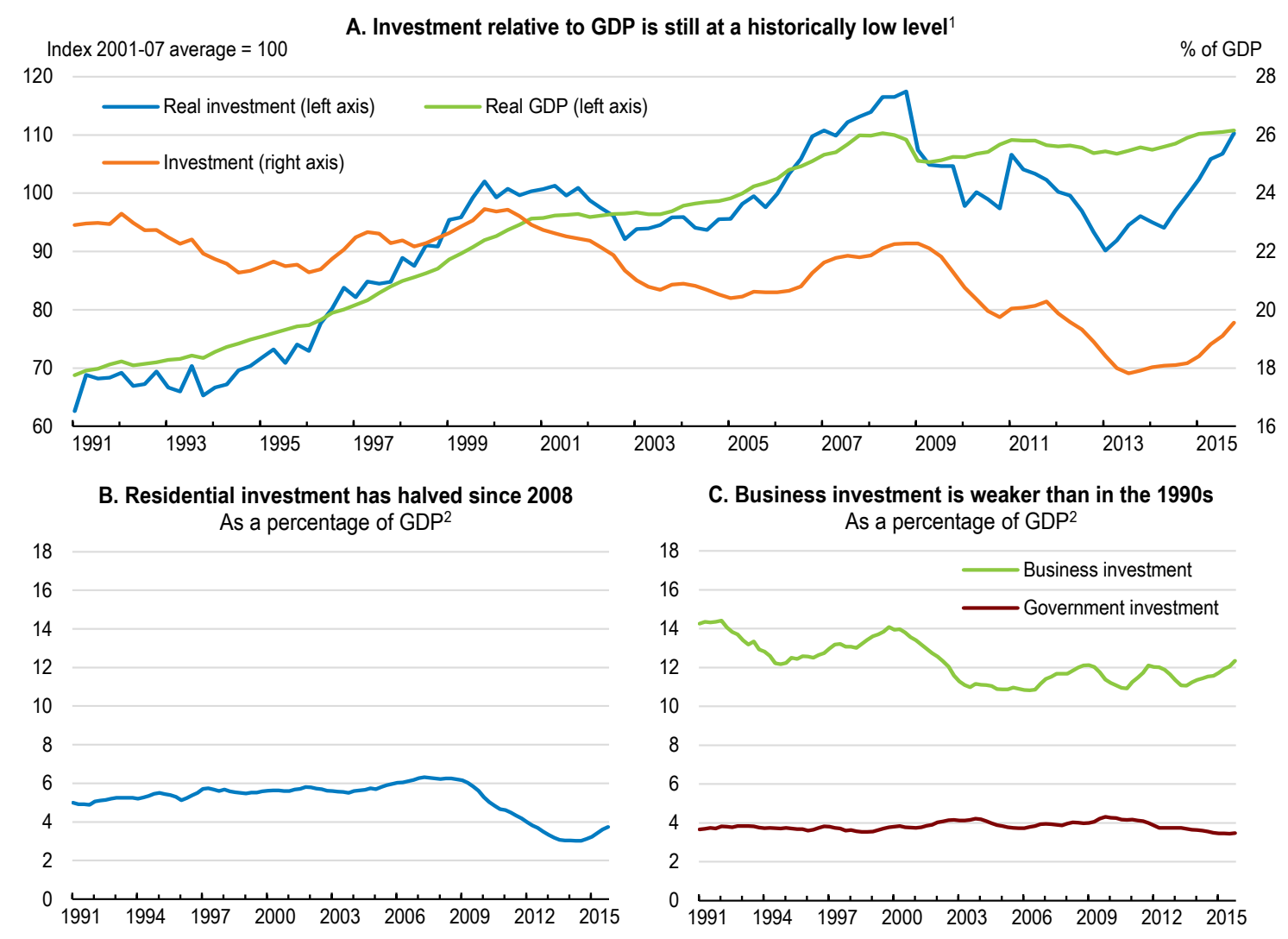

1. Investment refers to total gross fixed capital formation. 4-quarter cumulative data for investment expressed as a percentage of GDP.

2. In nominal terms. Investment refers to gross fixed capital formation. 4-quarter cumulative data.

Source: OECD (2016), OECD Economic Outlook: Statistics and Projections (database), February.

1 Sanne Zwart is an Economist in the OECD Economics Department, contact email: sanne.zwart@oecd.org. The author is grateful to Pierre Beynet, Robert Ford, Rafał Kierzenkowski and Álvaro Pereira for their valuable comments and suggestions on earlier drafts, as well as for discussions with Dutch government officials and independent experts. Special thanks are due to Gábor Fulop for statistical assistance and Amelia Godber and Sylvie Ricordeau for editorial assistance. 
The slump in overall investment of recent years was mostly caused by the severe housing crisis (Figure 1, Panel B). For a long period, rising house prices had been sustained by low housing supply and a growing availability of mortgages with loan-to-value ratios of over $100 \%$ and no principal repayment until maturity, as discussed in Chapter 1 of the 2014 Economic Survey (OECD, 2014a). House prices were further supported by a generous tax treatment of mortgage debt and policies that resulted in a large proportion of the housing stock being used for social housing, as discussed in Chapter 4 of the 2010 Economic Survey (OECD, 2010). When the banking sector and the economy were hit by the crisis in 200708 , house prices followed with a lag, and the downturn was aggravated by uncertainty regarding reforms of the mortgage debt relief. These reforms were contemplated by the authorities for several years and were finally introduced, although very gradually, in January 2013. By the end of that year, nominal house prices had fallen by more than $20 \%$. The depressed housing market weighed on residential investment, which as a share of GDP almost halved during 2008-13.

Despite the rapid house price increases before 2007, the pre-crisis period was not characterized by overinvestment in housing, as was the case in several other European countries that experienced overheating in house prices. Residential investment had been rather stable during the preceding 10 years, hovering between $5.5 \%$ and $6.0 \%$ of GDP, and the annual additions to the housing stock were broadly in line with demographic developments (Figure 2, Panel A). The 40\% drop in new construction since 2008 is large given the fall in house prices (Figure 2, Panel B), and preliminary numbers indicate that construction rebounded in 2015 on the back of the ongoing housing market recovery and the resumption of economic growth. However, the rebound in new construction has not been large enough to be the main driver of the growth in housing investment, which instead seems to have been driven by housing transactions, similar to investment in commercial real estate having been due to land transactions (Figure 2, Panel C). Unfortunately, no data on the various components of residential investment are available, as opposed to, for example, for the United Kingdom (Bank of England, 2015).

Business investment had slowed down during the early 2000s, but it held up relatively well during the crisis (Figure 1, Panel C). It has been relatively volatile though, declining in about half of the quarters since 2007. To a large extent, the overall pattern of business investment reflected developments in overall economic activity, as periods of subdued investment broadly coincided with the double-dip in GDP of 2008-09 and 2012-13. During the last decades, real GDP growth of 1\% was associated with a 2.3\% increase in business investment, which is somewhat higher than the $1.7 \%$ found for a group of OECD countries (Lewis et al., 2014), and investment indeed strengthened considerably just shortly after the resumption of economic growth. 
Figure 2. Plunge in new construction was not caused by overinvestment
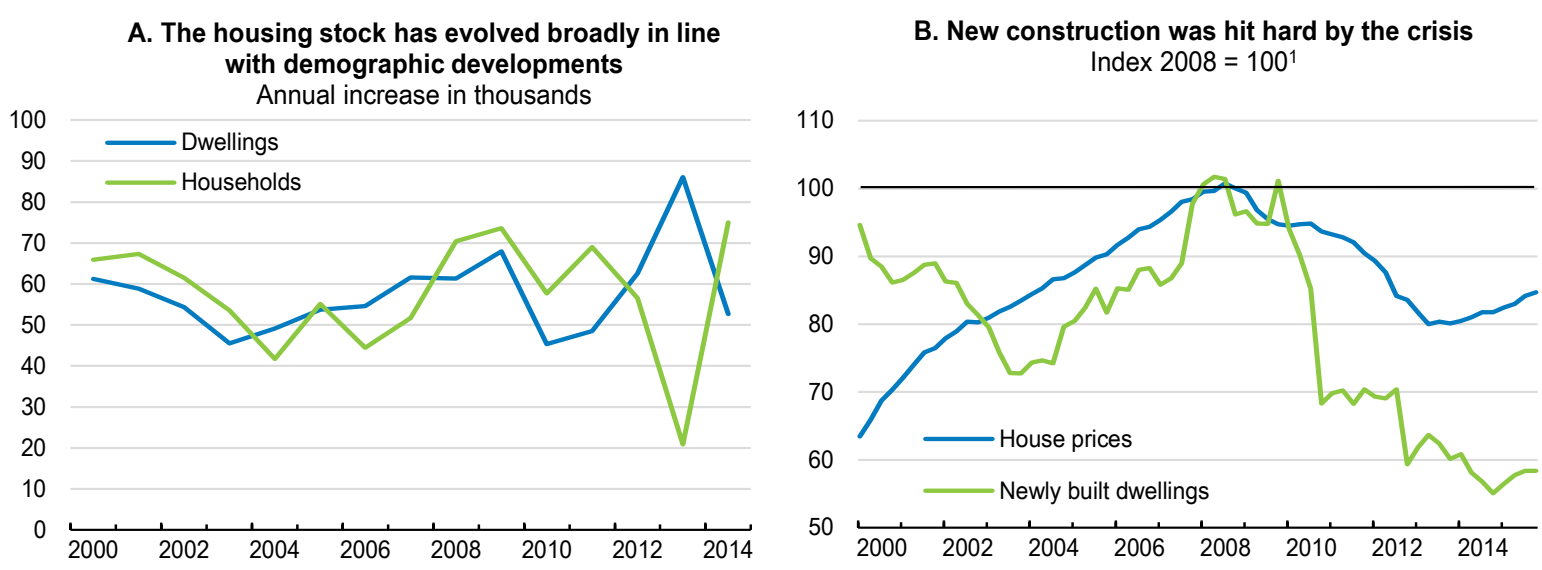

C. Land transactions have recently been driving investment in commercial real estate Year-on-year percentage change with contributions ${ }^{2}$

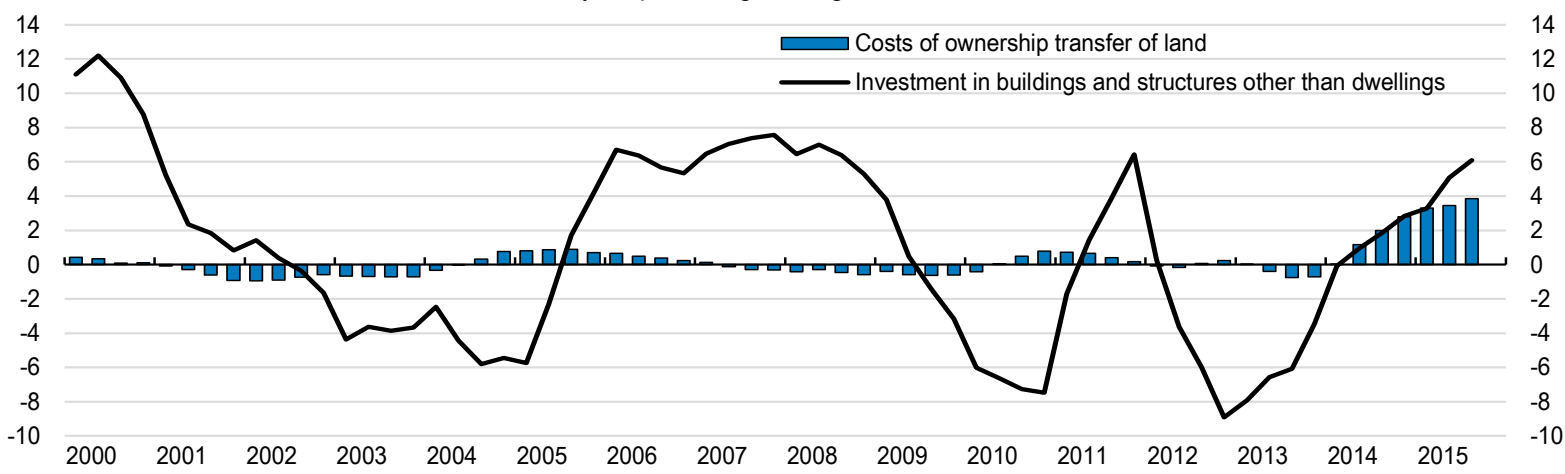

1. House prices refer to price index of existing own homes that are located on Dutch territory and sold to individuals. 4-quarter moving average applied for newly built dwellings. There is a structural break in 2012 in the series for newly built dwellings.

2. In 2010 prices. 4-quarter moving average. Sum of contributions from investment in buildings other than dwellings, other structures and costs of ownership transfer of land exceed the growth rate of investment in buildings and structures other than dwellings.

Source: Statistics Netherlands (2016), "Households; key figures", in Population, Statline, February; Statistics Netherlands (2016), "Changes in the dwelling stock", in Construction and housing, Statline, February; Statistics Netherlands (2016), "House Price Index; existing, Netherlands", in Construction and housing, Statline, February; and Statistics Netherlands (2016), "Quarterly National Accounts, values", in Macroeconomics, Statline, February.

Net investment has slowed down as a changing composition of the capital stock has raised replacement needs. The capital stock is depreciating at a rate of $5.5 \%$, up from around $3.2 \%$ two decades ago. As real gross fixed capital formation has more or less stalled, while a larger share is used for replacements, the resulting plunge in net investment has caused the growth rate of the productive capital stock to fall to one-third of its long-term pre-crisis average (Figure 3, Panel A). The slowdown in capital per worker has been an important reason for the lower trend productivity growth during the crisis (Figure 3, Panel B; OECD, 2015b). Excess production capacity and muted growth prospects have been weighing on companies' investment decisions in recent years, but as the economy is now on a firmer footing, stronger net investments would support future productivity growth. 
Figure 3. Lower capital-per-worker growth weighed on trend productivity
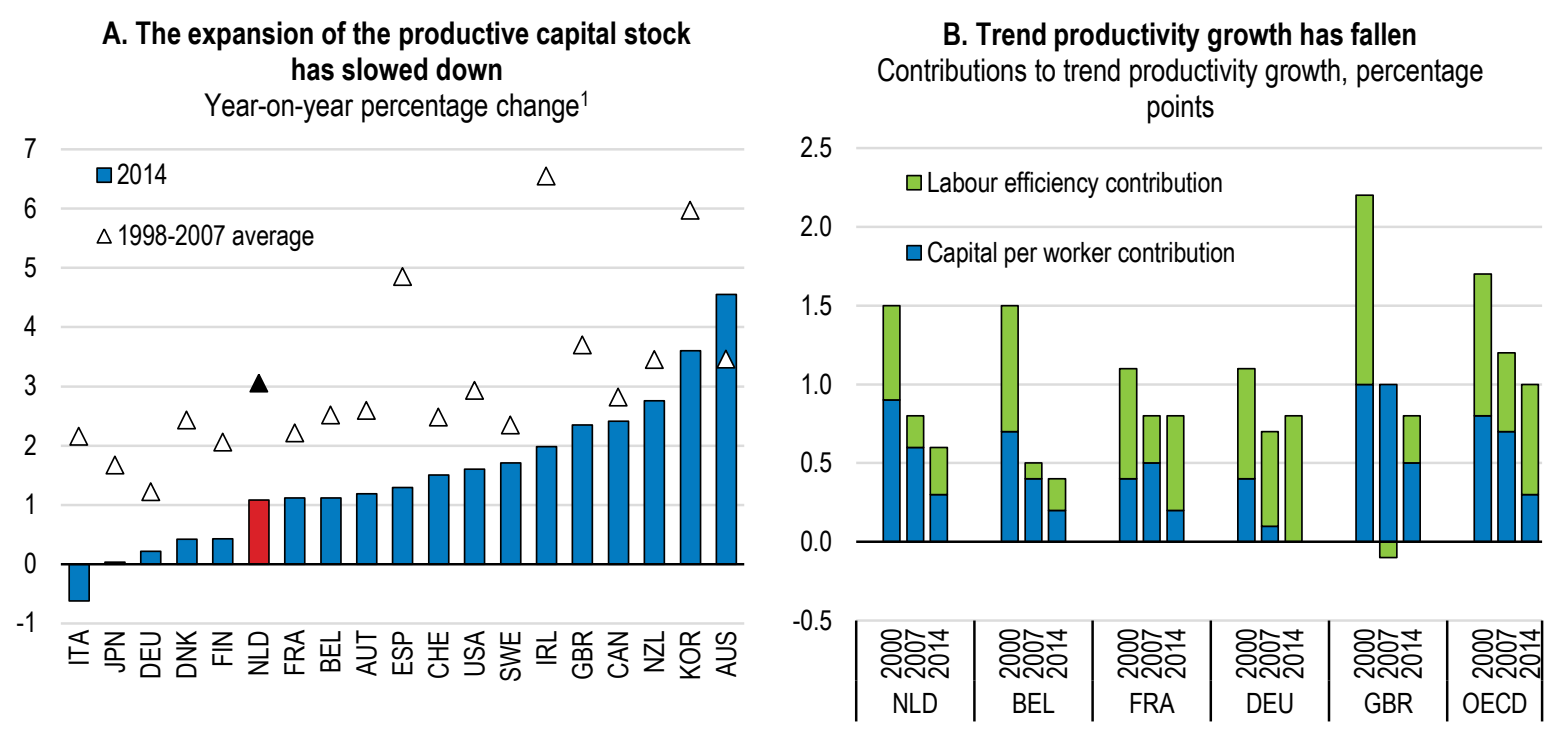

1. 2013 instead of 2014 for Australia, Belgium, Denmark, Finland, Germany, Ireland, Japan, New Zealand, Spain, Switzerland and the United Kingdom. Productive capital excludes investment in housing.

Source: OECD (2016), OECD Economic Outlook: Statistics and Projections (database), February and Ollivaud, P. and D. Turner (2015), "Re-Assessing the Contribution of Weak Investment to the Post-Crisis Slowdown in Trend Productivity and Potential Output Growth", OECD Economics Department Working Papers, forthcoming.

Public investment held up relatively well during the crisis, and the quality of infrastructure is perceived as the world's fourth best (WEF, 2015). Public investment as share of GDP increased slightly in the first years of the crisis due to fiscal stimulus measures, but subsequent efforts to reduce the budget deficit caused a modest decline (Figure 1, Panel C). Estimations suggest that the public capital stock in 2014 accounted for about 55\% of GDP, similar to the level in 1995 (Eijking and De Jong, 2015). The Netherlands thus fared better than the many other northern European countries, such as Germany, which experienced a decline, although it had not taken advantage of the low interest rates to expand the public capital stock. As the public infrastructure is in general good shape, this paper focuses on private investment.

\section{Bolstering private investment to support the housing market and boost growth potential}

Residential investment has to increase from the current low level to meet the growing demand for housing and the changing needs. Between now and 2030, the population is expected to grow by only around $4 \%$, but due to shrinking household sizes the number of households should increase by nearly $10 \%$, which amounts to 45000 per year (CBS, 2015a). In particular, as the population ages, the number of single-person households is set to increase by close to 20\% during 2015-30 and the demand of "singlefloor" housing will expand even faster (EIB, 2015a). Another 20000 to 25000 new dwellings will be needed annually to replace part of the current housing stock (EIB, 2015a), and the recent hike in the inflow of refugees creates another need for housing and could require an additional 40000 dwellings in 2016-20 (EIB, 2015a). However, since the 2008 fall in residential investment, the number of newly built houses has covered only two-thirds of the long-term need. Although new construction is now rising, additional investment is needed. Raising the low energy efficiency of the current housing stock (Buildings Performance Institute Europe, 2015) requires investment as well.

Demand for private rental housing is set to increase in particular. The high rent increases in recent years indicate that rentals in the middle and upper segment are relatively scarce. Moreover, demand is set 
to increase further as young people are postponing the acquisition of their first house and recent reforms aim to make social housing more expensive for households with relatively high incomes. Boosting private investment in rental housing is needed to mitigate further upward pressures on rents.

Turning to non-residential investment, an indication of the gap between current levels and long-term needs can be obtained from the steady-state investment-to-output ratio and the OECD long-term growth projections (OECD, 2014b and 2015a; Lewis et al., 2014). The estimated shortfall in non-residential investment is over $2 \%$ of potential GDP (Figure 4) and closing this gap would require lifting investment by $15 \%$. The investment gap would be twice as large if structural reforms would raise trend output growth and a continuation of the upward trend in the depreciation rate would raise the depreciation rate, by 0.5 percentage point each.

Figure 4. Gap between non-residential investment needs and actual investment is substantial Estimated gap between steady-state needs and non-residential investment as a percentage of potential GDP, 2014 Q4 -2015 Q3 $^{1}$

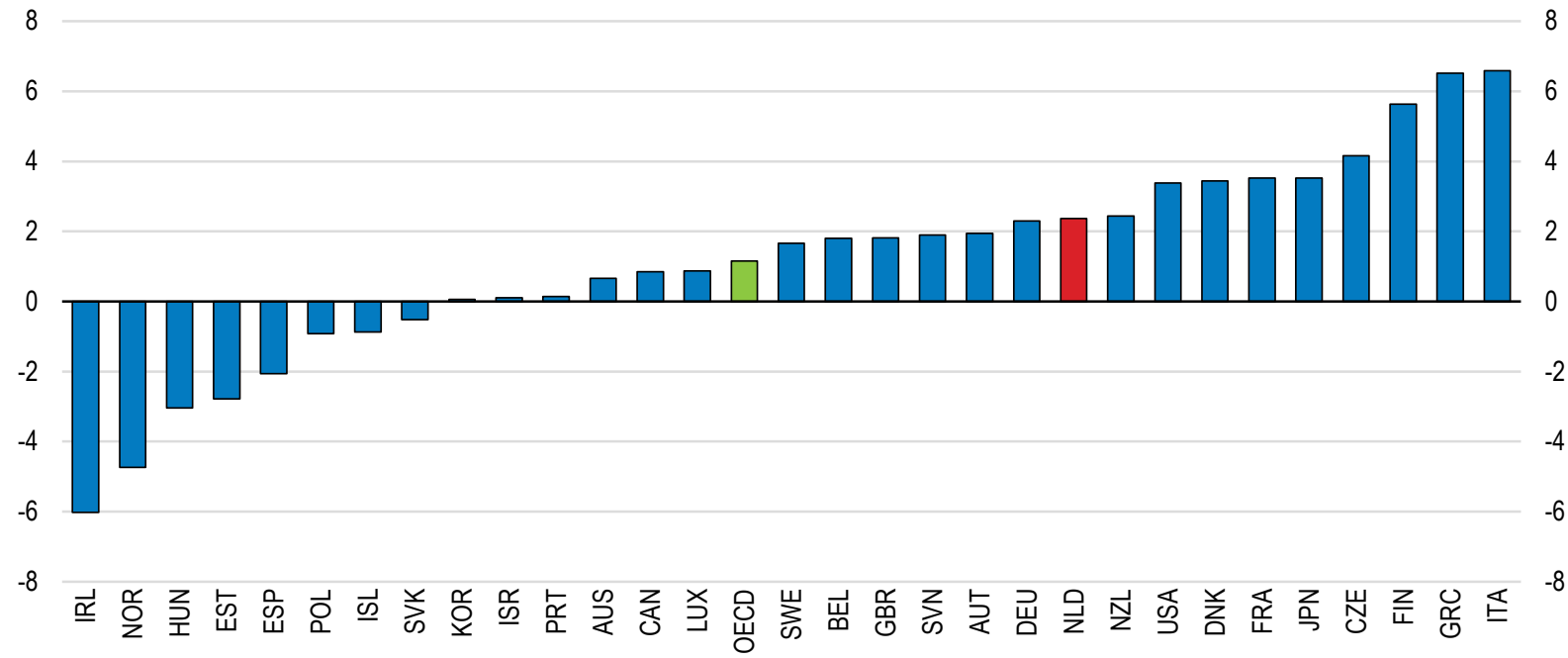

1. 2014 for Hungary and Poland. The OECD aggregate covers 30 countries and it is calculated as an unweighted average of the data shown.

Source: OECD (2015), OECD Economic Outlook, Volume 2015 Issue 1, June and OECD (2016), OECD Economic Outlook: Statistics and Projections (database), February.

The changing economic structure is not reducing investment needs. Between 2000 and 2014, the service sector was expanding, while the manufacturing sector was shrinking (Figure 5), as the Netherlands is increasingly specialising in services both before and after the actual production of goods (CBS, 2015b; Los et al., 2014). However, business services are making considerable investments in intangible assets, and as their overall capital intensity has been broadly comparable to that of manufacturing, in particular a decade ago, the shift has had only a small effect on the level of business investment. When including other economic activities, the changing economic structure affected investment only marginally. The lower overall investment intensity is thus almost entirely due to the changing investment intensities of individual economic activities. In particular, investment of business services as share of gross value added was about a third lower in 2014 than in 2000, and this was the main driver of the observed fall in investment in this period. Part of this decline is due to weaker business prospects during the crisis and increased difficulties to arrange financing; another part reflects falling prices of information and communications technology (ICT), although their overall impact is tempered by the small share of related investments. 
Figure 5. Lower investment by business services has driven the decline in investment intensity Arrows indicating the change between 2000 and $2014^{1}$

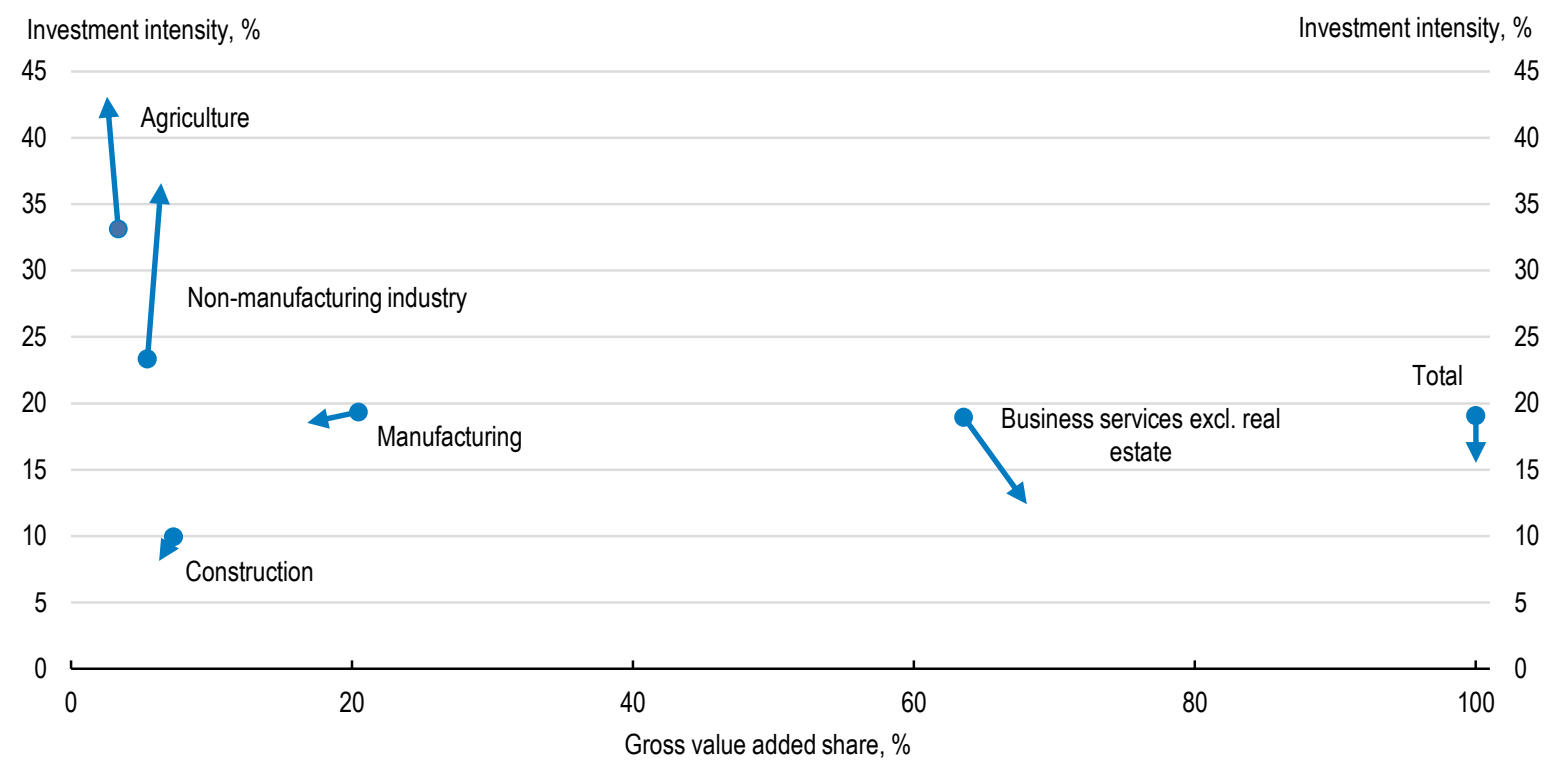

1. Investment intensity refers to the share of non-residential investment in gross value added. Non-residential investment is calculated as total gross fixed capital formation (GFCF) minus GFCF in dwellings. Business services excluding real estate refers to all services activities (G-U) minus real estate activities (L), public administration and defence, compulsory social security $(\mathrm{O})$, education $(\mathrm{P})$ and human health and social work activities $(\mathrm{Q})$.

Source: OECD (2015), OECD National Accounts Statistics (database), November and Eurostat (2015), National Accounts (ESA 2010) (database), November.

Technological developments caused a rapid increase in ICT investment since 2000 (Figure 6, Panel A), which does reflect higher volumes and significant quality improvements. Investment in ICT is an import driver of productivity (Andrews and De Serres, 2012), and sectors in which ICT is intensively used are increasingly becoming the main driver of economic growth (Adalet McGowan et al., 2015). In a highly innovative country as the Netherlands, investment in ICT has already a large impact: it accounts for nearly $45 \%$ of the contribution of capital to value added growth, despite only making up around 5\% of total investment costs (CBS, 2015c).

Investment in intangibles has a large effect on growth as well, but has slowed down relative to other countries. Investment in intangibles, which according to the national accounts definition includes research and development (R\&D) and software, has stalled relative to gross value added, and the Netherlands is no longer among the OECD countries with the highest ratios (Figure 6, Panel B). These investments, as well as those in other intangible assets such as advertising, marketing research and organisational capital, are important sources of growth (CBS, 2015c; Corrado et al., 2013; OECD, 2013a).

This paper analyses how private investment can be enhanced in the Netherlands. First, boosting residential investment in the private rental sector would improve the housing market, as would raising efforts to make the financing of owner-occupied housing more sustainable. Second, further improving the conditions for business investment, especially investment in R\&D and innovation and in new companies, and stepping up support for environmentally-friendly investments would support long-term and sustainable growth. Third, business investment can be reinforced by improving access to finance, in particular bank loans and alternative sources of finance. 
Figure 6. Investment in ICT equipment has grown fast, but investment in intangibles has stalled

\section{A. Investment of business sector by asset type Index $2000=100^{2}$}

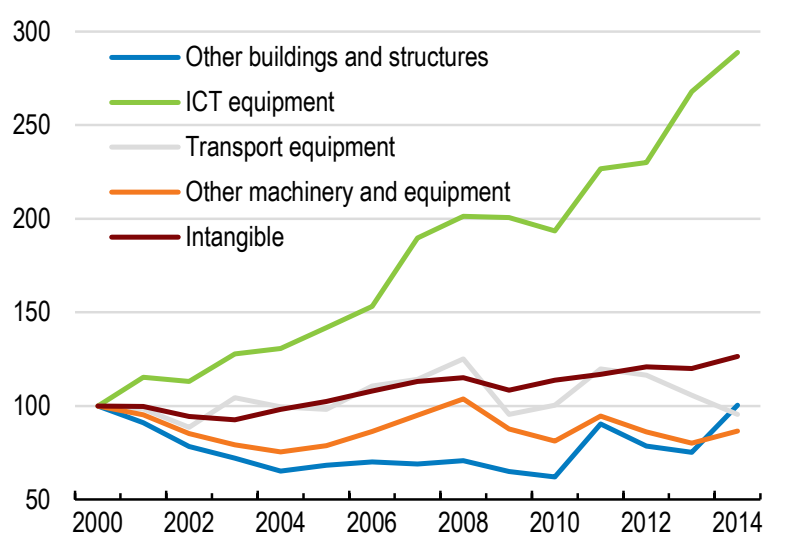

B. Business investment in knowledge-based capital (KBC)

As a percentage of gross value added of business sector excluding real estate, $2013^{3}$

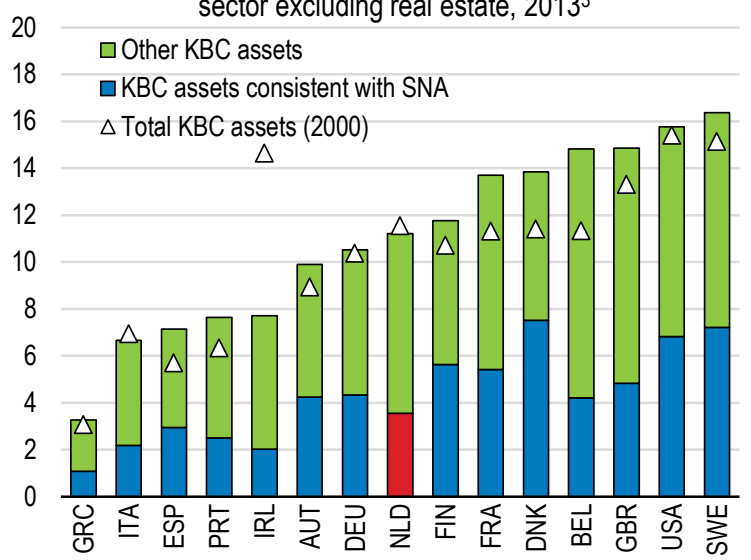

1. Data refer to business sector excluding real estate (i.e. all activities minus real estate activities (L), public administration and defence, compulsory social security $(O)$, education $(P)$ and human health and social work activities $(Q))$.

2. In volume. Investment refers to gross fixed capital formation. Intangible investment refers to intellectual property product that includes computer software and databases as well as research and development. ICT: information and communication technology.

3. KBC assets consistent with the definition in the System of National Accounts (SNA) include: software, R\&D, entertainment, literary and artistic originals, and mineral exploration. Other KBC assets include: design, new product developments in the financial industry, brands, firm-specific training and organisational capital.

Source: Eurostat (2016), National Accounts (ESA 2010) (database), February; OECD (2015), OECD Science, Technology and Industry Scoreboard 2015: Innovation for growth and society; and Corrado, C., J. Haskel, C. Jona-Lasinio and M. lommi, (2012), "Intangible Capital and Growth in Advanced Economies: Measurement Methods and Comparative Results", Working Paper, June, (available at http://www.intan-invest.net).

\section{Promoting private rental investment}

The housing sector mainly consists of owner-occupied dwellings, with most of the remainder being social rental housing. The number of owner-occupied houses almost doubled during 1986-2012, raising its share from $45 \%$ to $60 \%$ of the total housing stock (Ministerie van Binnenlandse Zaken en Koninkrijksrelaties, 2013). The number of rental houses, however, remained broadly stable. Rental houses, which according to a point-system should have rents below the rent control threshold (EUR 710.68 in 2015), are subject to rent regulation which limits both the maximum rent and annual rent increases. Around $35 \%$ of all households live in rental houses with regulated rents, which is by far the highest share among OECD countries (Andrews et al., 2011). Over $80 \%$ of regulated rentals concerns social housing owned by corporations as the private rental sector is small, accounting for $20-25 \%$ of rental dwellings and $10 \%$ of all dwellings.

Spending on housing has increased since the outbreak of the crisis, but remains moderate compared to other OECD countries (Figure 7). Subsidies for low-income earners, rent controls and generous tax advantages for mortgage interest hold housing costs low. However, the unregulated rental market is relatively expensive as this is the only tenure without public support. Moreover, demand for unregulated rentals outstrips supply, causing rents to increase in cities in particular. Demand is even set to increase further as recent reforms for social housing allows for larger rent increases for higher-income earners, although so far the effects have been limited, and for fixed-term contracts after which a tenant's qualification needs to be reassessed. In addition, the reduction of mortgage interest relief and tighter loanto-value requirements force first-time buyers to wait while saving for a down payment. 
Figure 7. Household spending on housing has increased, but remains moderate

As a percentage of gross adjusted disposable income of households ${ }^{1}$

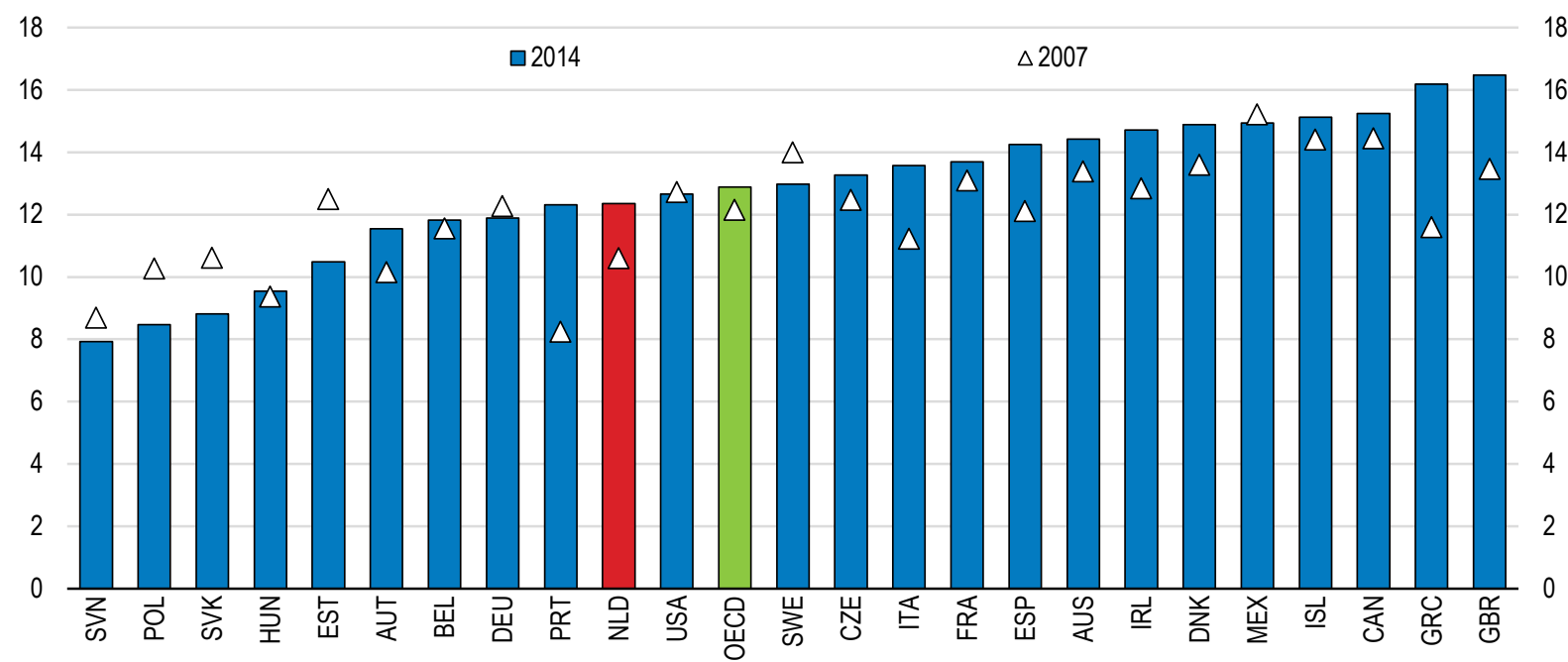

1. In nominal terms. Disposable income adjusted for social transfers in kind. 2013 instead of 2014 for Australia, France, Iceland, Mexico, the OECD aggregate Poland, Spain and the United States. Spending on housing refers to actual rentals for housing, imputed rentals for housing and maintenance and repair of the dwelling. For Australia and the United States spending on housing excludes maintenance and repair of the dwelling. The OECD aggregate covers 25 countries and it is calculated as an unweighted average of the data shown.

Source: OECD (2016), OECD National Accounts (database), February.

\section{Bolstering investment in the private rental market}

Housing policies contributed to underinvestment in the private rental sector. Low-income earners can benefit from stringent rent regulation applying to those social and private dwellings, which have monthly rents below the rent control threshold. They have few incentives to leave once their incomes rise. Higherincome earners are supported in becoming home-owners by tax advantages that are larger for higher levels of income and mortgage debt (RLI, 2015). The large subsidies for renting in the regulated market and for homeownership have crowded out investment in rental dwellings with monthly rents above the rent control threshold. In addition, rent regulation for private rentals below this threshold reduces returns for landlords, which limits private investment in this segment. In particular, rent controls lower the profitability, and hence the supply, of single-person housing as for almost all such dwellings the point-system results in a rent below the rent control threshold. Finally, the large tax benefits for home-owners also hamper the development of private rental housing, as prospective owners can anticipate the benefits and bid more for new building plots.

The small size of the unregulated rental sector limits the functioning of the housing market. The relative scarcity of unregulated rentals limits the options for the part of the population that is not willing or able to enter the owner-occupied market and that has no access to the social housing market, while other people, e.g. young people, singles and childless couples, could also be better served by a greater availability of unregulated rental dwellings (De Boer and Bitetti, 2014). In addition, the small unregulated rental market clogs the regulated housing sector, and thus contributes to the long waiting lists there, as people whose income or family situation no longer qualify them for social housing, cannot find new rental housing easily. Finally, renters typically have a higher residential mobility, and a larger unregulated rental sector would thus help to reduce traffic congestion and improve labour market outcomes (OECD, 2010).

Further limiting strict rent controls in the private rental sector would boost residential investment. Some recent reforms are already supporting the development of the private rental market, but they may not 
be sufficient to address the large needs. For example, since October 2015, the house value partly determines the maximum initial rent, but the weight would need to be increased further to support the provision of unregulated dwellings in areas with high market demand, such as the main cities. Allowing rents for new tenants to better reflect market rates would increase financial incentives for private landlords to undertake investment and would thereby mitigate further upward pressures on rents. It would in particular support the provision of single-person housing, as due to the low rent control threshold these dwellings are currently almost necessarily subject to the strict rent regulation.

From 2017 onwards, corporations will have to administratively or legally separate commercial activities from the provision of social housing, which is welcome. Competition by the not-for-profit housing corporations limited the provision of rentals by private parties (OECD, 2010). The corporations often charge below-market rents, even for dwellings with rents above the rent control threshold, which makes it difficult for private investors to compete in the unregulated segment. Corporations also often get discounts when buying plots and can benefit from a state guarantee when borrowing. However, since 2012 corporations are no longer allowed to subsidise their commercial activities through measures intended as support for social housing. As a result, they have stepped up the sale of mostly larger dwellings. Although this reduced their presence in the unregulated rental market, the houses sold usually ended up in the owneroccupied sector and thus did not add much to the supply of private rentals. The separation of commercial and social activities should be done rigorously, and requiring corporations to divest their commercial branches would allow them to focus more on their core task.

\section{Safeguarding sustainable residential investment to maintain an adequate housing stock}

Authorities see sufficient scope for the construction of new housing in urban areas to meet growing demand, especially if some of the stringent local planning regulations were relaxed. Municipalities in the economic core (Randstad) are set to expand more rapidly than in the rest of the country. New constructions are subject to the Sustainable Urbanisation Procedure of 2012 (Ladder voor duurzame verstedelijking), which aims for an efficient use of the scarce space without being overly prescriptive, and both municipalities and investors have been involved making the procedure simpler and easier to apply. Housing construction in urban areas is picking up rapidly, especially in Amsterdam where it reached a height in 2015. The conversion of empty offices could potentially provide 25000 additional housing units, which is about 5\% of the demand until 2025 (Deloitte, 2015).

Three-quarters of available building plots are owned by municipalities, following large investments in land, partially driven by speculation motives, in the years before the housing market bust. When the book value of land had to be revised downwards subsequently, municipalities incurred losses, at least notional, that so far amount to EUR 4 billion. A revision of accounting rules in 2016 aims to reduce land speculation by municipalities, which is welcome, although the short-term effect on the provision of building plots has to be monitored closely.

The financial sustainability of residential investment would be strengthened by accelerating the reduction of mortgage interest relief and lowering the maximum loan-to-value (LTV) ratios for new mortgages. The outstanding mortgage debt of Dutch households is very high in international comparison (OECD, 2014c; OECD, 2014a), and due to the crisis a quarter of households had outstanding mortgages above their house value in 2015 (Rabobank, 2015a). Since 2013, mortgage interest relief has been reduced very gradually, but the recovery of the housing market and the low interest rates provide favourable conditions for stepping up the pace. The government also decided to reduce the maximum LTV ratio by 1 percentage point per year until it reaches $100 \%$ in 2018. This increases the financial resilience of especially young buyers, makes banks less dependent on market funding and reduces the risk of boom-bust cycles (CPB, 2015b; DNB, 2015a). Nevertheless, the new limit would still be relatively high, as, for example, the typical LTV ratio for a first-time house buyer in the euro area was nearly $80 \%$ in 2007 . The gradual 
reduction of the LTV limit should therefore be continued beyond 2018 until the limit is $90 \%$, as recommended by the Dutch Financial Stability Committee (Financieel Stabiliteitscomité, 2015), or even further (IMF, 2015b), especially if a further reduction in the tax relief for mortgages proves politically infeasible (CPB, 2015b).

Stepping up investment in energy efficiency improvements of dwellings would help to meet energy reduction targets. The Dutch housing stock provides ample room for energetic renovations (Meijer et al., 2010). Home-owners can apply for a subsidy or a loan with a low interest rate from the National Energy Fund to finance energy efficiency improvements, and improving isolation is supported by a lower valueadded tax (VAT) rate. Following the 2013 Energy Agreement, subsidies exist for rental housing in the regulated sector, though, and landlords are in general allowed to raise the rent after the renovation. Increasing public support for energy enhancing investments in existing housing regardless of tenure and extending it to cover new construction that replaces old dwellings would help to reduce final energy consumption by the committed $1.5 \%$ per year and to reach the 2020 reduction target for greenhouse gas emissions. Positive economic effects could limit the budgetary costs (Ecofys, 2015), although the experience of other countries indicates that the subsidies need to be carefully designed to achieve planned reductions in energy use (OECD, 2015c).

\section{Providing the right incentives for business investment}

Strengthening the current rebound in business investment would support future potential growth. After a long period of subdued domestic demand, the economic revival has boosted investment recently. Further bolstering investment conditions, including the tax and regulatory framework, government support and access to finance, would help to turn the cyclical upswing into a durably higher level. Specific measures could stimulate investments in innovation, start-ups, clean energy and green growth.

\section{Promoting investment in innovation and $R \& D$}

The Netherlands is a highly innovative country, but safeguarding its position requires to step-up investments. Expenditures on $\mathrm{R} \& \mathrm{D}$, which besides investment in assets also covers wage costs, have increased from $1.7 \%$ of GDP in 2010 to $2.0 \%$ in 2013, but are still considerably below the target of $2.5 \%$ set for 2020, which itself is lower than the European Union (EU) average of 3.0\%. Public expenditure has fallen between 2010 and 2013, and although as a percentage of GDP it remains above the EU average, peers such as most of the northern European countries, have higher budgets relative to GDP. The proportion of business spending in total R\&D expenditure is lower than in many other countries, which reflects that business investment in R\&D is well below the OECD average, or just average when adjusted for the industrial structure (OECD, 2013b). Policies to support innovation and R\&D combine specific generic policies with support for the most innovative sectors, the top sectors.

The top sector policy supports innovation, and hence competitiveness, by promoting entrepreneurship and co-ordination among businesses, government and knowledge institutes in the strongest economic sectors. Strengthening the diffusion of innovation from top sectors to the rest of the economy would boost growth, as in general companies at the frontier are experiencing much faster productivity growth than those further away (OECD, 2014d; Adalet McGowan et al., 2015). A welcome move in this direction is the programme "SME Innovation Promotion Regions and Top Sectors" (MKB-Innovatiestimulering Regio en Topsectoren, MIT) of 2015. This programme is funded by the central government and the regions and provides more than EUR 50 million in subsidies to stimulate innovation by small and medium-sized enterprises (SMEs) across provincial borders. Demand was much higher than the available budget, which suggests that strengthening the cross-regional policy dimension could also be useful. Doing so would also better align the top sector approach with the EU smart specialisation agenda, which emphasises the regional dimension of innovation (OECD, 2014e), provided that the efficacy of the support is not affected by a wider range of objectives. 
Generic support for $R \& D$ is more concentrated on tax incentives, as opposed to direct funding, than in most other OECD countries (Figure 8; OECD, 2014f and OECD, 2015d), and the overall mix may excessively favour incumbents and be less suited for more risky and longer-term innovation activities. Tax incentives of the main programme, the Research and Development Promotion Act (Wet Bevordering Speur- en Ontwikkelingswerk, WBSO), are well designed, leading to a high take-up by SMEs and start-ups. The higher budget in 2016, which makes up for the discontinuation of a corporate income tax allowance for R\&D, will be particularly beneficial for companies without profits. However, direct funding as share of GDP is well below that of peer countries, which leaves relatively little room for influencing the scope and ambition of innovation and the apparent need for parts of the Dutch business sector, and might not fully exploit the potential of co-operation between science and industry (OECD, 2014d). The reliance on tax incentives also risks tilting public support towards established companies. Stepping up support with a more specific focus, for example the recently announced EUR 130 million programme for healthcare innovation, could help to leverage private sector innovation in promising sectors and potentially "disruptive" technologies.

Figure 8. Support for business R\&D is skewed towards tax incentives

As a percentage of GDP, $2013^{1}$

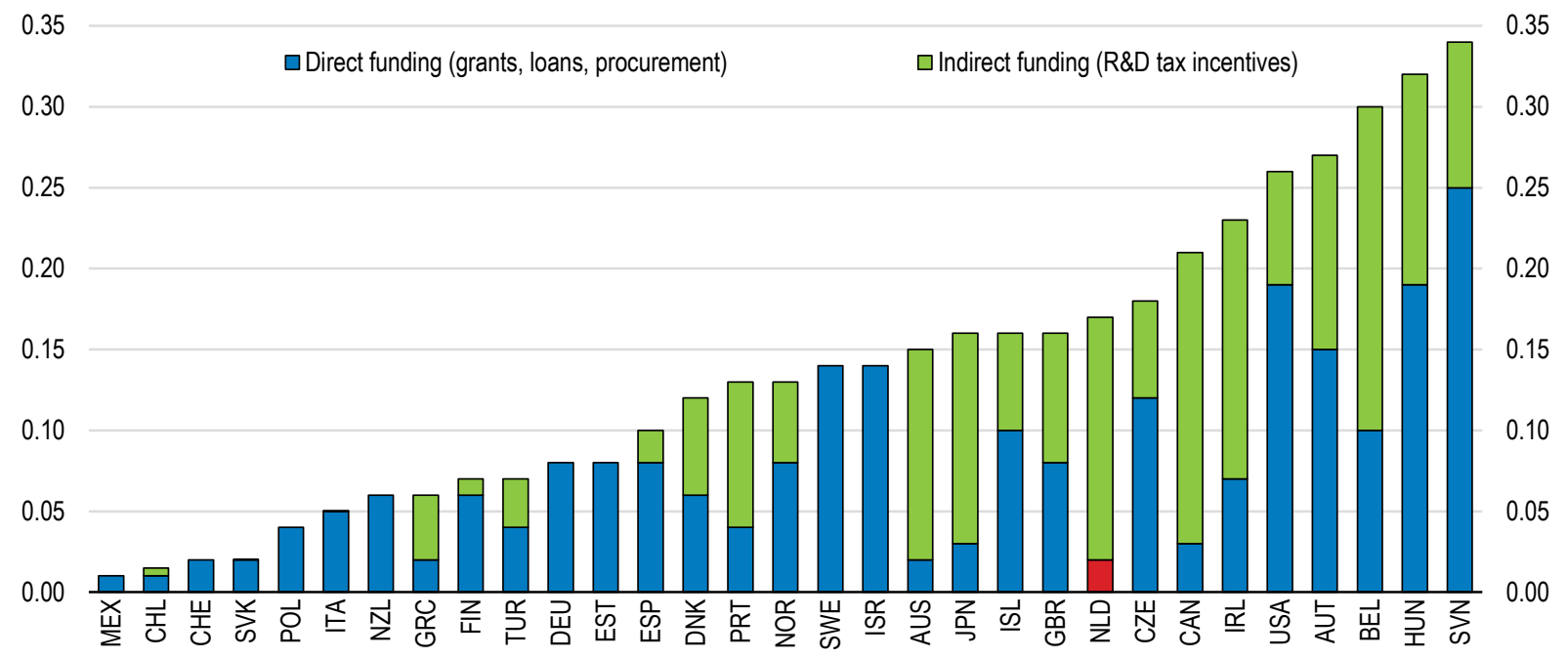

1. 2012 for Belgium, Ireland, Israel, Spain, Switzerland and the United States. 2011 for Australia, Iceland and Mexico. Estonia, Germany, Mexico, New Zealand, Sweden and Switzerland did not provide information on expenditure-based research and development (R\&D) tax incentives for 2013. For Israel, the R\&D component of incentives cannot be identified separately at present. No data on the cost of expenditure-based R\&D tax incentive support are available for Poland. Estimates do not cover sub-national and income-based R\&D tax incentives and are limited to the business sector (excluding tax incentive support to individuals). Data refer to estimated initial revenue loss (foregone revenues) unless otherwise specified.

Source: OECD (2015), OECD Science, Technology and Industry Scoreboard 2015: Innovation for growth and society.

The planned changes in tax support for innovation activities are welcome, but questions about its impact remain. Innovation-related profits that qualify for the innovation box are taxed at 5\% instead of the standard corporate tax rate of $25 \%$, which is among the lowest rates in Europe, although the qualifying income matters as well for a full assessment of the tax systems' generosity (OECD, 2014d). However, it is in general not clear how effective innovation (or patent) boxes are in addressing market failures, and whether they represent value-for-money (OECD, 2015e). An innovation box does not necessarily foster experimentation and might even steer companies to particular types of research in order to reap the benefits as much as possible. Moreover, support typically goes to larger firms, including multinationals. The authorities plan a change in tax advantages consistent with OECD recommendations regarding Base Erosion and Profit Shifting (BEPS). Unfortunately, it is complicated to evaluate the effectiveness of 
innovation boxes, but an international comparison indicates that their impact is low, both compared to $R \& D$ tax incentives and patent boxes in other countries (CPB, 2014).

Ensuring sufficient and coherent investment in ICT infrastructure is needed to boost innovation. For example, the penetration of standard broadband is high, but only $10 \%$ of broadband subscriptions in 2014 were for fibre connections, which is lower than the OECD average and much lower than the $70 \%$ in Korea and Japan (OECD, 2015f). More investment is needed to maintain the high standard of public ICT infrastructure for education and research institutes. Recently, the top sectors stepped up coordination of ICT infrastructure development, and further strengthening such an integral approach would allow for a better focus and a more adequate reaction to new developments and challenges (AWTI, 2015).

\section{Supporting investments of start-ups and SMEs with growth ambitions}

SMEs account for about half of total business investment, the same as large firms (Figure 9). SMEs are less capital intensive than large firms, though, as reflected by an investment share that is below their labour share. SMEs and large companies allocate a similar percentage of their investments to intangibles. As in other OECD countries, the SME sector has become less dynamic in recent years (Criscuolo et al., 2014), although the vast majority of existing Dutch SMEs are not planning to grow, the share of fastgrowing SMEs is high (OECD, 2015g). Supporting start-ups and young SMEs is important as they are quickly reacting to new opportunities and technologies. Facilitating SMEs with growth potential to invest and expand would also support economic growth.

Figure 9. SMEs and large firms each account for half of business investment

Percentage share by firm size, $2012^{1}$
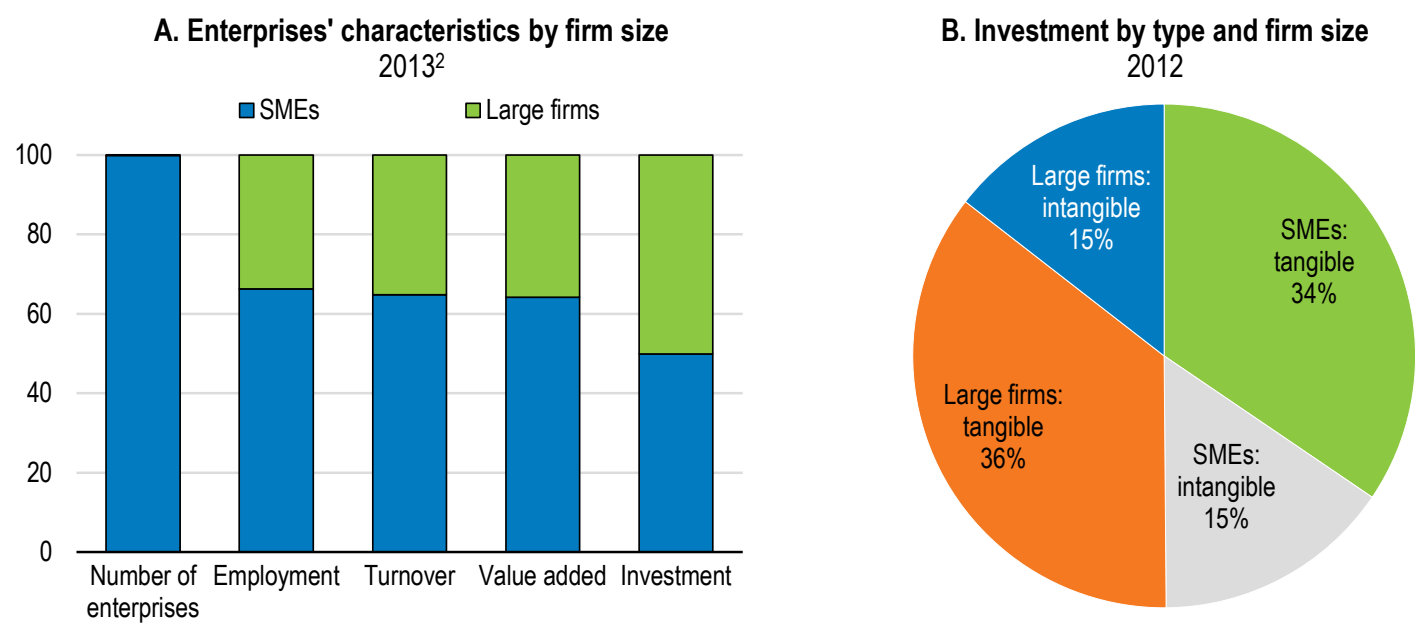

1. Small and medium-sized enterprises (SMEs) are defined as having 0-249 employees.

2. Data for investment refer to 2012.

Source: OECD (2016), "Structural business statistics ISIC Rev. 4", Structural and Demographic Business Statistics (database), February and Statistics Netherlands (2015), "Investeringen uitgesplitst naar bedrijfsgrootte conform totalen Nationale Rekeningen", May.

Addressing regulatory and tax bottlenecks would help start-ups and attract financing for investment. A wide range of financial support is already available to support innovation by young firms and financing of young or fast-growing companies (see below). To identify bottlenecks for start-ups, the Ministry of Economic Affairs initiated the StartupDelta initiative, where start-ups, investors, launching customers, governments and knowledge institutions work together to boost the start-up eco-system and connect it to 
other international start-up hubs. StartupDelta made several welcome recommendations to make the tax system friendlier for start-ups, in particular reducing income taxation for entrepreneurs by allowing those whose start-ups do not make profits to pay themselves a wage, making it fiscally more attractive for entrepreneurs to pay employees with options in the firm and introducing a more favourable treatment for providers of venture capital (StartupDelta, 2015).

Support for innovation that could lead to major breakthroughs should be complemented by an accommodative regulatory framework that allows for a quick adoption of new technologies. Many new and fast growing firms use new technologies and business models, and maintaining an accommodating regulatory stance is needed to provide sufficient space for innovation and to spur related investment. Societal and technological developments offer possibilities for companies, but overly restrictive regulation could risk smothering entrepreneurship. Current institutions that safeguard the public interest and quality can pose obstacles for new companies as they are based on incumbents (Camps, 2015; OECD, 2015e). Authorities are in general supportive of new initiatives and willing to adapt regulations. For example, the Ministry of Infrastructure and the Environment decided that taxis are no longer required to have a taxi meter or issue paper receipts, and is actively engaged in initiatives to develop self-driving cars. An example at the local level is the city of Amsterdam, where a violation of regulation by new businesses will not only result in a sanction, but also in a review of related regulation. However, adjustment can take a long time, which would call for making regulation more technology-neutral, for example by stipulating the public interest to be ensured, while allowing companies flexibility in deciding how to achieve this (Camps, 2015).

\section{Stepping up investment in clean energy and green growth}

Green innovation in the Netherlands risks falling behind. Less than $1 \%$ of the government budget on R\&D was related to the environment in 2012-13, down from over 3\% in the early 2000s (OECD, 2015c), while a further decline is projected (Van Steen, 2014). During 2010-13, the Netherlands fell from seventh to thirteenth place in the EU eco-Innovation Scoreboard (EIO, 2014). In only three of the nine top sectors is sustainability an integral part of planned innovation contracts (OECD, 2015c).

Investment in renewable energy has raised the share of renewables in gross final energy consumption, but meeting the official target could be challenging. Renewable energy sources accounted for $5.5 \%$ of energy consumption in 2014, up from $4.8 \%$ a year earlier. However, it remains one of the lowest in the EU, while the distance to the target for 2020, $14 \%$ for the Netherlands, is one of the largest (Figure 10). The official forecast indicates that the target will not be met (ECN, 2015).

Figure 10. Meeting the target for renewable energy is at risk

Share of renewable energy in gross final energy consumption, percentage ${ }^{1}$

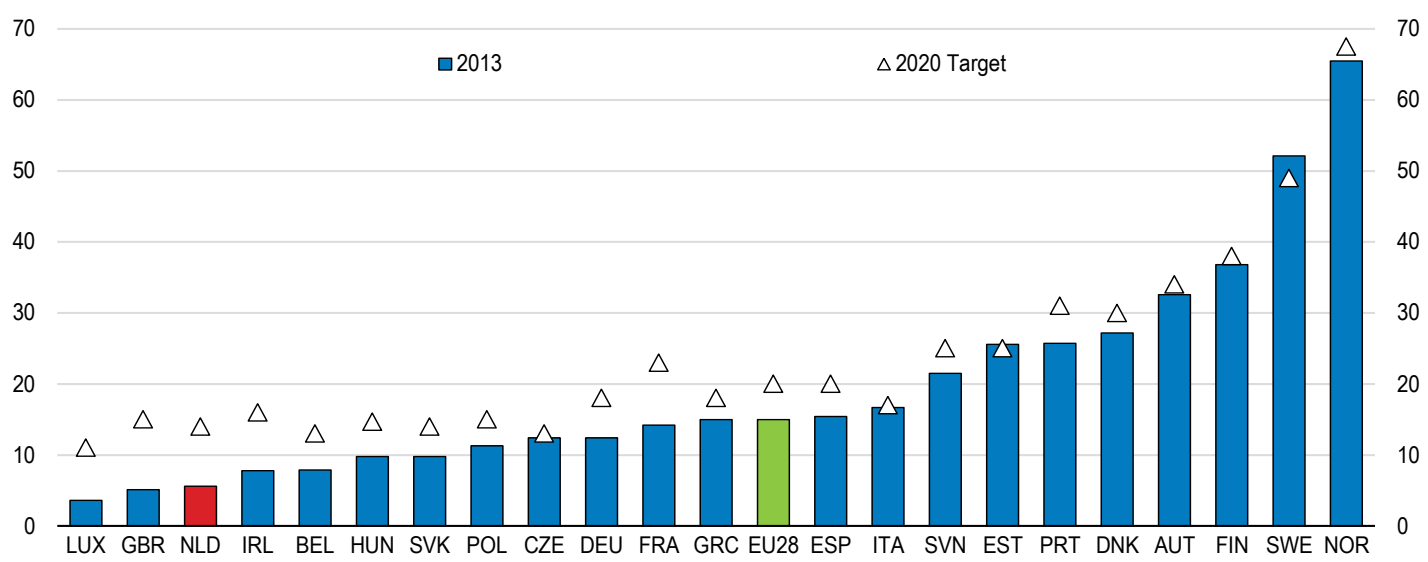

1. The EU28 aggregate refers to the European Union.

Source: Eurostat (2016), "Climate change and energy", in Europe 2020 Indicators, February. 
The National Energy Agreement of 2013 includes several measures to step up renewable energy production, while raising the target to $16 \%$ by 2023 . It emphasises that further developing wind energy, which already accounts for almost half the renewable energy, is crucial. The Offshore Wind Energy Bill adopted in 2015 clears the way for more wind parks off the coast, and tenders for new parks will likely open in the first half of 2016. Plans for a large park to test new technologies were cancelled, but instead a smaller site that is integrated with a new park will be constructed. Co-firing biomass in coal-fired power stations would also help to reach the target, and is stimulated by the new Stimulering Duurzame Energieproductie (Renewable Energy Producers Subsidy, SDE+). Making subsidies available for projects abroad could be a cost-effective way to help meeting the target (Algemene Rekenkamer, 2015).

Investment in clean energy has been substantial during the past decade, but existing measures appear insufficient to reach the $1.5 \%$ annual savings of final energy consumption agreed under the energy agreement (OECD, 2015c). The Energy Investment Tax Allowance provides tax incentives for investment in energy-savings technologies and sustainable energy production, and green investment schemes provide for investment deductions and accelerated depreciation. Companies can also commit to implement energy efficiency plans in return for an exemption from energy taxes and this has led to significant energy savings. However, it is unclear whether taxing energy use would have provided better environmental outcomes (PBL, 2011), while the focus of the current renewable energy subsidy on low-cost and proven technologies could exclude more innovative technologies. Moreover, the budget for the support schemes has not been fully used due to several market barriers. Carrying out the evaluation of existing policy measures, planned for 2016, in a thorough, independent and transparent manner would provide a basis for improving the costefficiency of current instruments (OECD, 2015c).

A more active eco-innovation policy is needed to become a frontrunner again. As discussed earlier, a more balanced mix of tax incentives and direct public support for R\&D would allow for a better targeting and steer funding to areas where green innovation will support Dutch competitiveness (OECD, 2015c). Carrying out eco-innovation support through the mainly demand-driven top sector approach also risks underinvestment in applied publicly-funded research, which creates a gap in the eco-innovation chain between basic research and product development. Tightening demand-side measures related to regulation, standards and consumer policies, and stepping up partnerships with the private sector, in particular frontrunner SMEs, would also support green innovation.

\section{Further strengthening framework conditions for business investment}

Raising the potential return on investments by further strengthening framework conditions would buttress the rebound of investment that followed the recovery of domestic demand. Business conditions are in general good, and the Netherlands is among the top five competitive economies worldwide (WEF, 2015). Corporate governance policies support investor confidence, investment and capital allocation, and the overall framework for the private sector is largely in line with the OECD Principles of Corporate Government, while corruption perceptions are among the lowest in the world (Transparency International, 2014).

Business regulation promotes strong competition and stimulates companies to innovate and operate efficiently, and only few barriers remain. According to the OECD Product Market Regulation (PMR) indicator, the Netherlands is the least restrictive among all OECD countries (Koske et al., 2015). This strong performance reflects the limited direct and indirect involvement of the government in business operations. In addition, it is relatively easy to start a business, and barriers to trade and investment are very low as well. Room for improvement remains, in particular with regard to public ownership and vertical integration in the electricity and gas sectors, entry barriers to road transport, legal services and accounting, and the regulation of shop opening hours, and reforms in these areas would strengthen framework conditions for investment. Other potential reforms to strengthen business conditions include lowering the 
costs of starting a business, getting construction permits, and registering property; accelerating connection to electricity; improving the quality of judicial processes when enforcing contracts and lowering related costs; and strengthening the protection of minority shareholders (World Bank, 2015).

Bankruptcy legislation is among the most debtor-friendly systems, which supports investment of, among others, innovative firms by reducing the penalty of failure (Panteia, 2014). The costs of closing a business are limited compared to the estate's value. However, the relatively low level of creditor protection could hamper access to finance for young firms. Moreover, creditors' costs and uncertainty in case of a debt restructuring are further raised by the right of single creditors to block an arrangement. The revision of the Business Continuity Act currently under discussion would make the process more efficient by making out-of-court settlements binding if a majority of creditors agree, as is already the case in, for example, several other European countries.

The budget for maintaining the high quality infrastructure networks and undertaking new projects appears tight. Unlike many other OECD countries, fiscal consolidation did not lead to infrastructure investment shortfalls (OECD, 2015a), and public investment as share of GDP is above the EU average, although lower than in, for example, Finland and Sweden. In general, most infrastructure networks have broad coverage and do not require major extensions, but already $40 \%$ of the budget is spent on maintenance to keep infrastructure that was put in place some decades ago up-to-date, and this part of the budget will be a major driver of the required rise in spending, put by some estimates on $25 \%$ between now and 2040 (EIB, 2015a). Needs for new projects remain substantial though. For example, the economic recovery is increasingly leading to traffic jams, and in particular the access to cities and the mainports Rotterdam and Schiphol could become a bottleneck. However, budgetary space in the medium term is limited (Figure 11), and the projected budget for 2015-19 can only finance about half the projects that are currently being explored (EIB, 2015b). The foreseen budget does also not provide much room to act adaptively to challenges posed by a changing economic and spatial structure on existing infrastructure, and to opportunities stemming from new information technology. Hence, authorities should consider stepping up the budget for infrastructure, especially later on in the planning period, assuming that there is sufficient fiscal space.

Figure 11. Infrastructure budget has been almost fully allocated until 2028

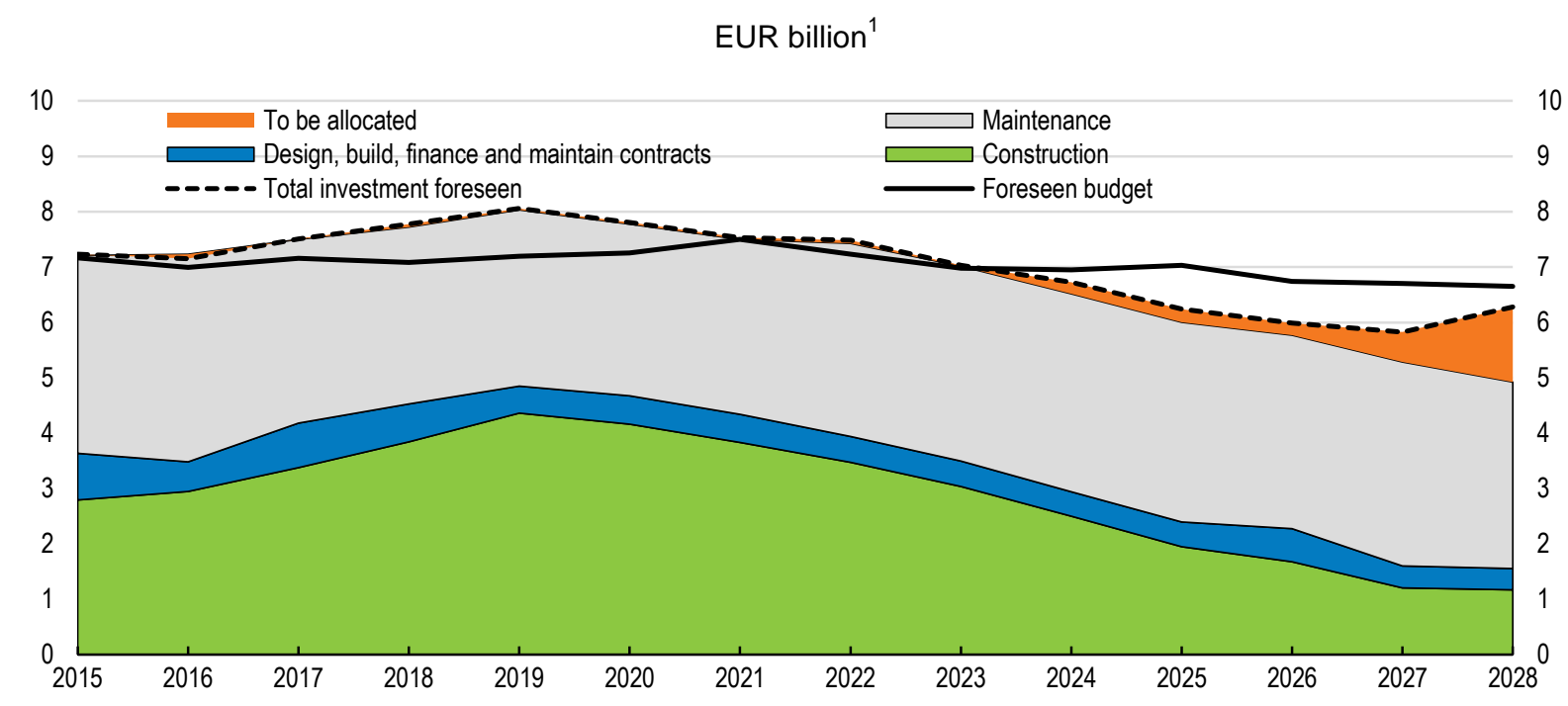

1. Data refer to the aggregate of two funds, namely the Infrastructure and Delta funds.

Source: Ministry of Infrastructure and the Environment. 
Despite the overall business friendly conditions and a high entrepreneurial spirit, birth rates of companies with employees are very low (OECD, 2015g). The churn rate, which reflects a country's degree of "creative destruction", is lowest among all OECD countries, and many firms do not have growth ambitions. Factors that limit business dynamics include stringent labour market regulations (OECD, 2014b), lack of the right skills, and perhaps high risk aversion of entrepreneurs. The importance of risk taking is widely recognised (Rutte, 2015), but cultural perceptions of failure might hamper entrepreneurship and only change slowly.

\section{Expanding financing for SMEs}

The crisis lowered companies' possibilities to finance investment from their own funds or to access external financing sources. During the crisis, the depressed business outlook reduced companies' appetite for investment, which was further constrained by their reduced financial health. Net operating profits as share of total assets remained low throughout the crisis, and dropped as recently as 2013, the last year for which data is available (Figure 12, Panel A). Lower profits made it more difficult to finance investments from own funds, while the reduced performance of companies also hampered their access to external finance. Although at first sight, the growing difference between corporate savings and investment suggests that companies have accumulated vast reserves, this is not the case as they steadily increased their investment abroad (Figure 12, Panel B). With the return of economic growth, profits have started to recover, as did investment appetite. During the first half of 2015, about 25\% all companies looking for external financing were doing so to finance investments, up from 18\% during the second half of 2014 (Panteia, 2015).

\section{Figure 12. Corporate profitability has fallen and growth in corporate savings has stopped}

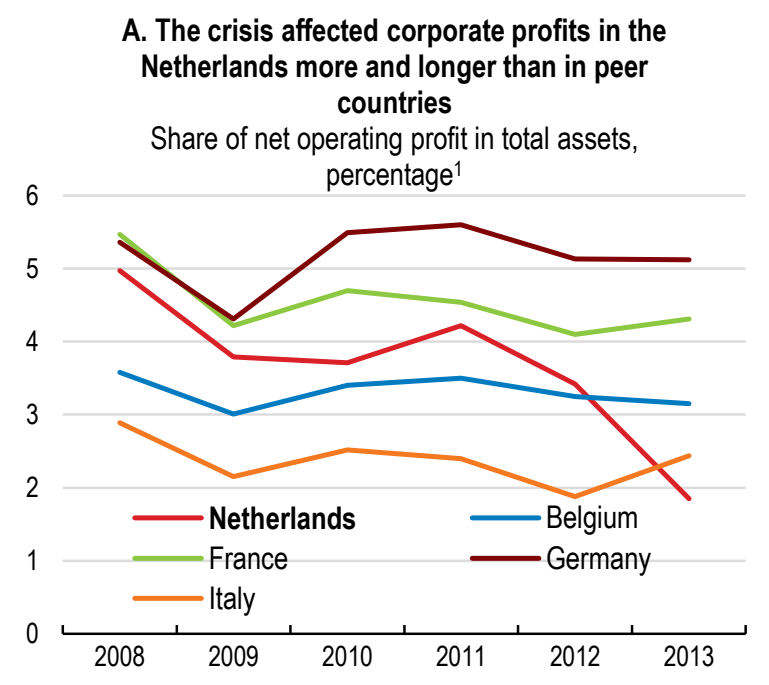

\section{B. Savings of non-financial corporations have been broadly stable since 2007 EUR billion}

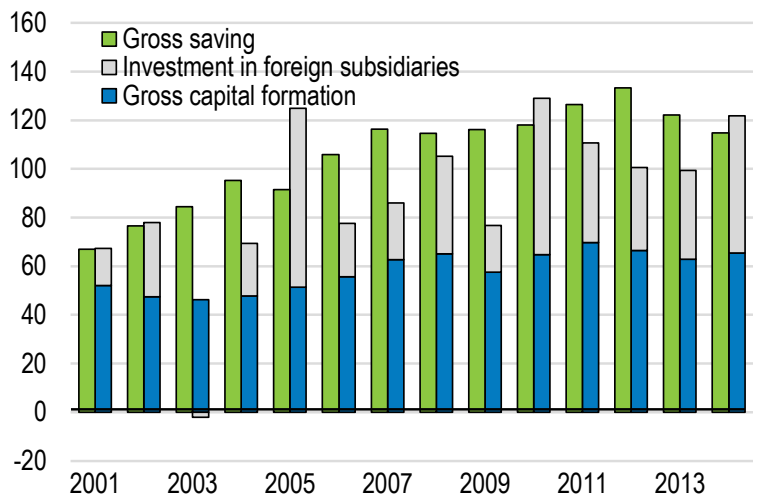

1. Total economy except for financial service activities, except insurance and pension funding and activities of head offices management consultancy activities. Small and medium-sized enterprises (SMEs) are defined as having an annual turnover of less than EUR 50 million.

Source: Banque de France (2015), BACH (Bank for the Accounts of Companies Harmonised) (database), November; Statistics Netherlands (2016), "Current transactions by sectors", in Macroeconomics, Statline, February; and Mark de Haan (2014), "De dalende investeringsquote", in De Nederlandse economie 2013, Statistics Netherlands, September.

\section{Improving access to bank financing}

Banks remain the dominant financing source for companies, although their share in companies' external financing has fallen to around $75 \%$ as large companies have been able to turn to market funding. For SMEs, considerable costs and their higher perceived riskiness often limits access to market funding, 
and they remain highly dependent on banks. The tax system provides incentives for debt-financing as interest payments are deductible from the corporate income tax base, while instead tax is levied over the return on equity investment (CPB, 2015c). Making equity investments more fiscally attractive from the viewpoint of both investors and companies would strengthen firms' balance sheets and support companies with high ambitions. The provision of equity would in particular benefit from making losses on venture capital tax deductible, as was the case before 2011.

Bank lending was hit hard during the crisis and the recovery of lending to SMEs is still hesitant. The volume of new loans fell sharply during the crisis (Figure 13, Panel A), and lending to remains weak (Figure 13, Panel B). Moreover, the availability of bank loans for SMEs is only slowly reviving (Figure 14). A thorough analysis of bank lending to SMEs is hampered by the lack of statistics. For example, data spanning a long period only differentiate between loans based on the loan amount instead of debtor size, SME-specific data have frequent changes in methodology which impede comparisons over time, and reporting across banks is not always harmonised. Improving reporting obligations would provide a more timely and reliable insight of SME bank financing (OECD, 2014a).

Figure 13. Bank lending is still bottoming out
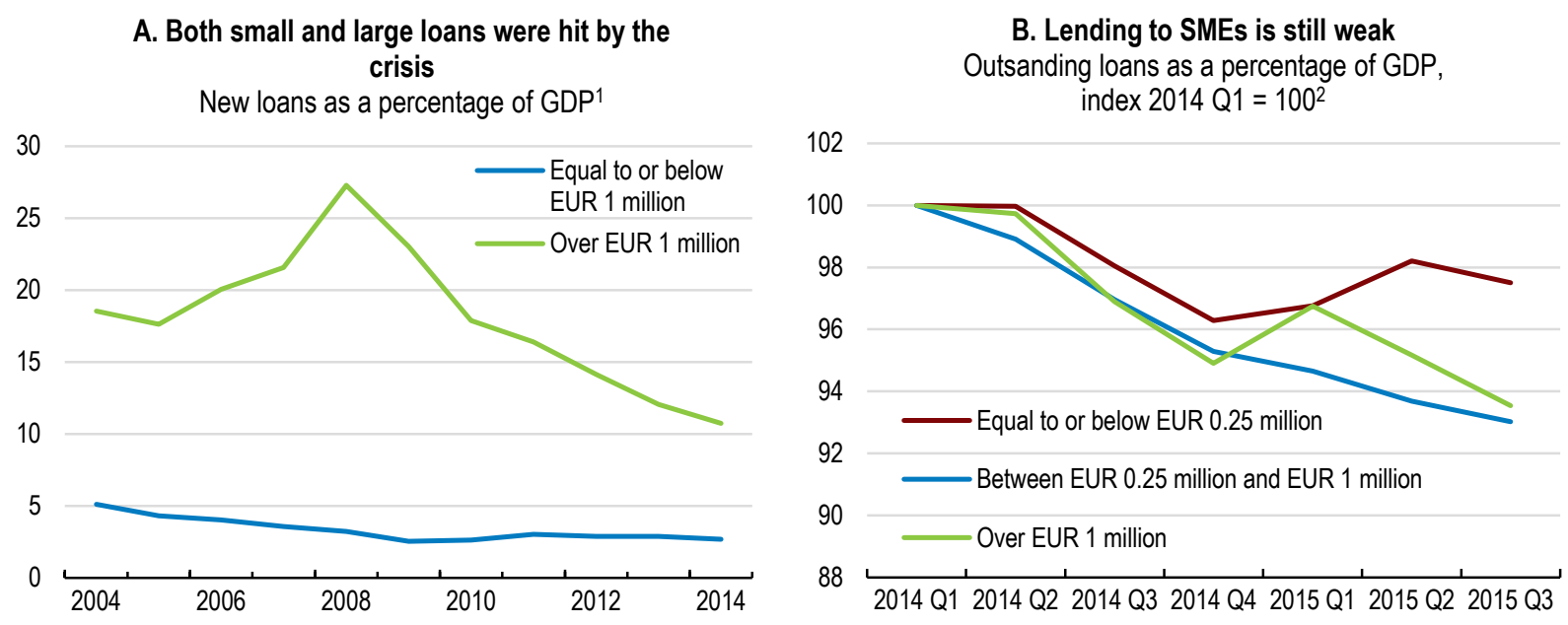

1. Excludes collateralised loans.

2. Lending by the three Dutch major banks to Dutch small and medium-sized enterprises (SMEs). SMEs consist of all privately owned companies and institutions which are involved in non-financial services or production of goods with the aim of making profit, and with a maximum turnover of EUR 50 million.

Source: DNB (2016), "Domestic MFI-statistics (monetary)", Statistics DNB, De Nederlandsche Bank, February. 
Figure 14. Bank lending constraints for small and medium-sized enterprises (SMEs) remain high

A. Reported by banks

Net weighted percentages of reporting banks ${ }^{1}$

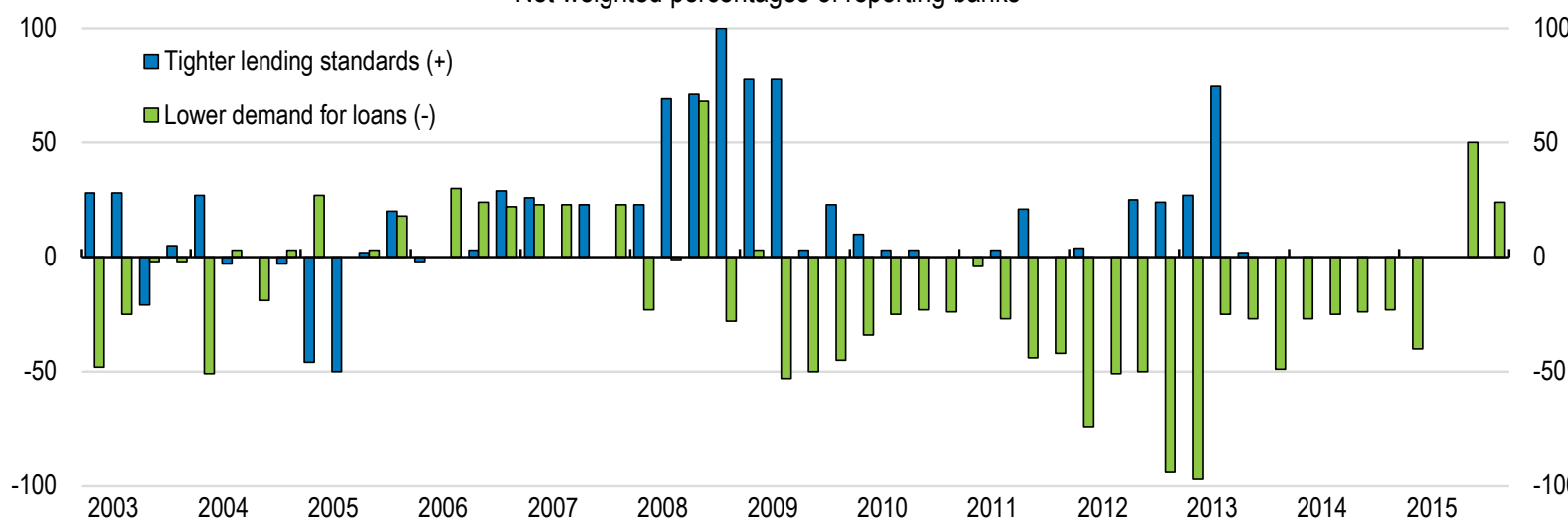

B. Reported by SMEs

As a percentage of all respondents, April to September $2015^{2}$

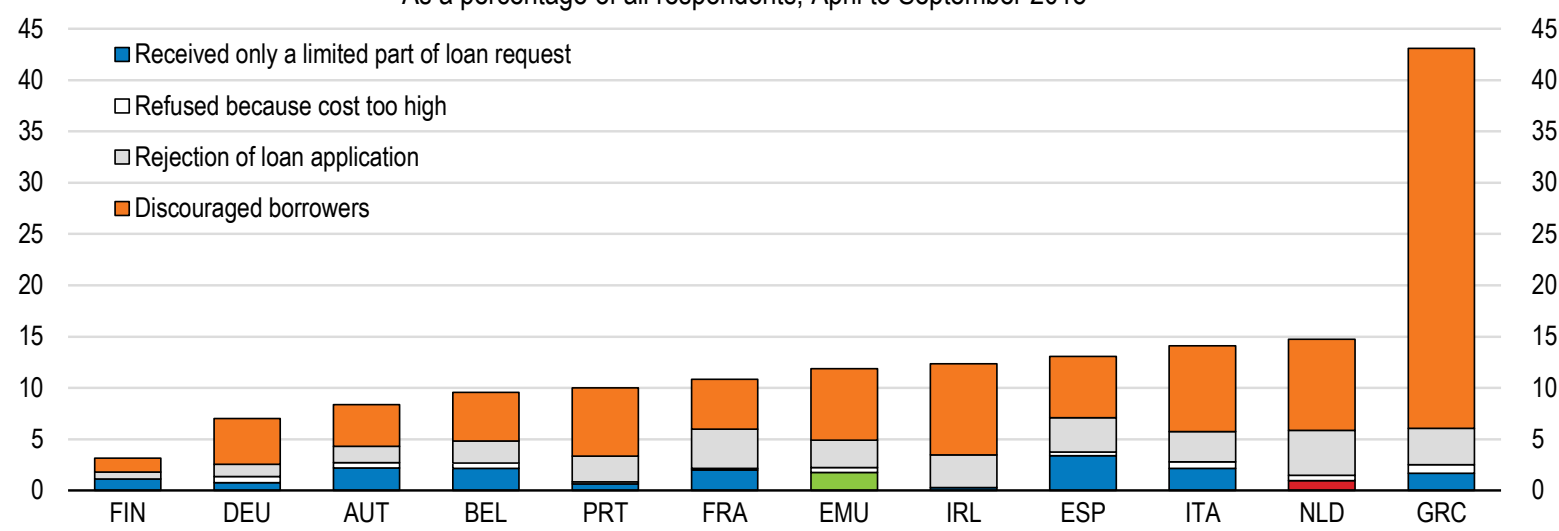

C. Reported by SMEs: rejection rates for credits of SMEs

As a percentage of respondents applying for a loan²

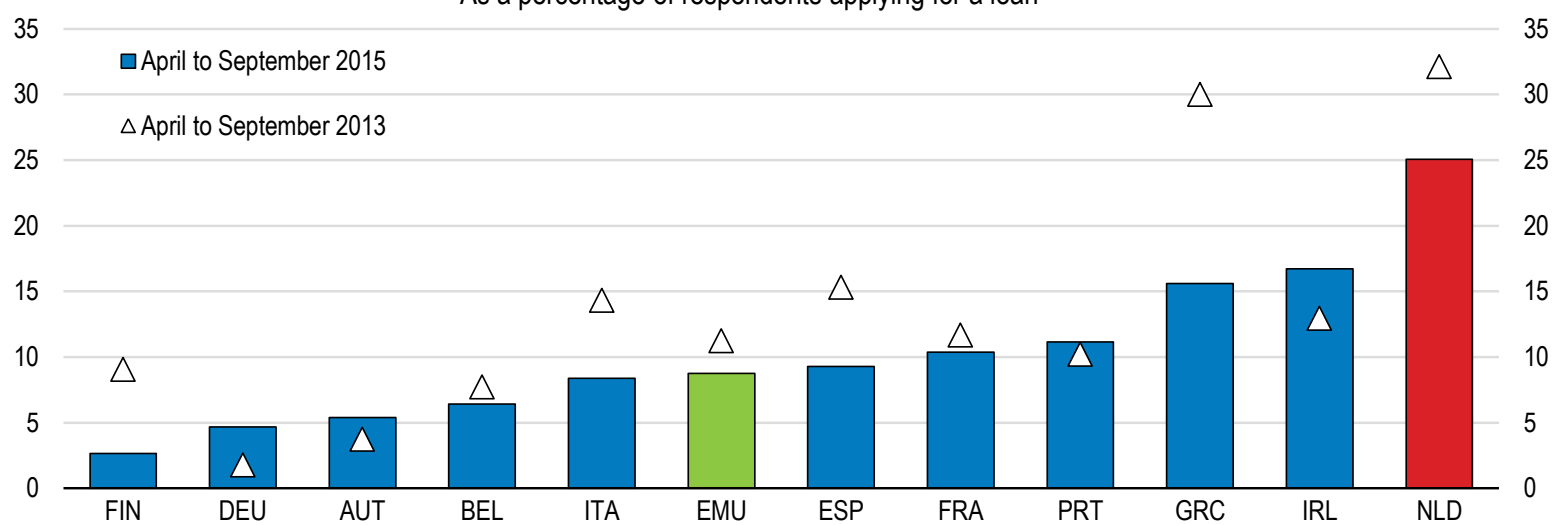

1. The values of net weighted percentages may vary between $+100 \%$ (i.e. all banks tighten their lending terms and conditions/all banks record an increase in demand for loan) and $-100 \%$ (i.e. all banks ease their lending terms and conditions/all banks record a decrease in demand for loan). The answers of the participating banks are weighted by their respective market share. SMEs are defined as having a net annual turnover of less than or equal to EUR 50 million.

2. SMEs are defined as having 0-249 employees. EMU: Euro area.

Source: DNB (2016), "Domestic MFI-statistics", Statistics DNB, De Nederlandsche Bank, January and ECB (2016), "Survey on Access to Finance of Enterprises", Statistical Data Warehouse, European Central Bank, January. 
Public programmes have prevented a further contraction of bank lending, but their efficacy and scope can be improved (OECD, 2014a). The various public programmes help a wide range of companies to obtain mainly bank financing (Box 1). Support was intensified during the crisis and in July 2015 through the Additional Action Plan SME-financing. The microcredit programme Qredits, which was launched in 2009 together with banks, has broadened the scope of companies served. The programme offers microcredit to young companies that cannot fulfil the regular loan criteria of banks due to lack of collateral, for example. The lending ceiling was raised twice and now stands at EUR 250000 to also cater for SMEs whose applications for bank loans failed, although the number of larger loans remains low. Lending has increased rapidly from just below EUR 10 million in 2010 to around EUR 28 million in 2014, although less than $20 \%$ of the loan applications are approved. Given the apparent shortage of ordinary bank lending for small entrepreneurs, the programme could be expanded, while an analysis of past loan approvals and rejections could indicate whether from a public point of view particular groups of entrepreneurs are underserved.

\section{Box 1. A wide range of public support programmes help companies obtain financing}

Three general programmes help companies obtain financing through providing guarantees (Figure 15). Small and mediumsized enterprises (SMEs) can benefit from the long-standing SME Guarantee Scheme (Borgstellingsregeling MKB, BMKB) to obtain easier access to bank loans. The programme Guarantee for Financing Entrepreneurship (Garantie Ondernemingsfinanciering, GO facility) was launched in 2009 and targets mostly larger SMEs. Although conceived as a temporary measure, the GO facility was made permanent in 2012. Both schemes aim to improve the access to credit of healthy companies that face financing constraints. However, due to limited insights into the extent of credit rationing, it is unclear what share of the BMKB reaches the target group and how the scheme can be improved (Algemene Rekenkamer, 2015; CPB, 2015). Estimates for the GO facility suggest that the extended guarantee has been crucial in obtaining financing in around $50 \%$ of the cases (De Jong et al., 2014). Reaching a larger share of the target group would also require raising awareness among companies, as only few have heard of either guarantee scheme (Panteia, 2015). A third general programme, Qredits, was launched in 2009 to help small entrepreneurs obtain microcredit.

Figure 15. Public programs supported SMEs' access to credit during the crisis and beyond $\square$ BMKB (SME Guarantee Scheme) $\square$ GO Facility (Guarantee for Financing Entrepreneurship) $\square$ Qredits (Microcredit)

A. Volume in EUR million

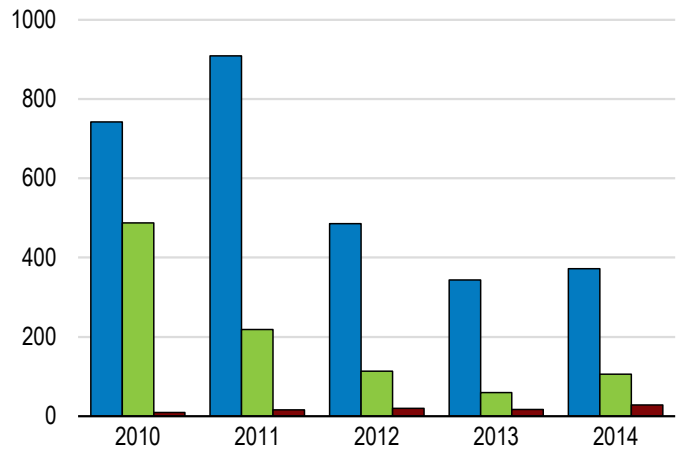

B. Number of beneficiaries

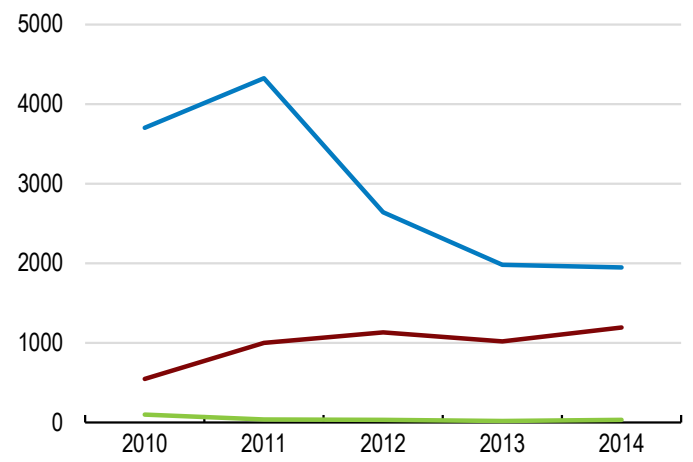

Source: Kamp, H. (2015), Letter to parliament regarding government support for the financing of entrepreneurship.

In addition to the general programmes, there is specific support for innovation. Through the SME+ Innovation Fund (Innovatiefonds $M K B+$ ), an amount of EUR 500 million was available for the period 2012-15 in the form of a credit for innovation, coinvestment for early-stage capital and a fund-of-funds. The Early Stage Financing (Vroege Fase Financiering) programme supports starters in assessing the potential of their business ideas and is in particular open to support the development of economic activities directly resulting from academic research. Around EUR 7 million was available for the second half of 2015. The Ministry of Economic Affairs has also stepped up guidance for SMEs that want to apply for Horizon2020 programme of the European Commission.

Source: Algemene Rekenkamer (2015), Resultaten verantwoordingsonderzoek 2014 Ministerie van Economische Zaken (Result of the accountability analysis 2014 Ministry of Economic Affairs); CPB (2015), Inzicht in the bmkb (Insight into the bmkb), CPB notitie; De Jong, J. H. Doornbos, H. Stoops. I. van den Berk and A. Ziegelaar (2014), Evaluatie garantiefaciliteit Ondernemingsfinanciering (GO): Eindrapport (Evaluation guarantee facility business financing (GO): Final report); and Panteia (2015), Financieringsmonitor 2015-1 Onderzoek naar de financiering van het Nederlandse bedriffsleven (Financing monitor 2015-1: Analysis of Dutch private sector financing). 
Banking sector concentration is high, holding back competition in the market for retail loans. Around 92\% of bank loans to SMEs are extended by one of the three big banks (ACM, 2015). The interest rate charged on these usually small loans is much higher than that on large loans, and the difference is large in international comparison (Figure 16). Since the crisis, lending margins have increased steadily. Meanwhile, competition has declined: some smaller domestic banks have been taken over by larger ones or stopped lending to SMEs and several foreign banks have decided to halt their lending activities in the Netherlands. No new banks have entered the market for retail loans in more than a decade, but less concentration and more diversity would improve stability and efficiency of the sector (DNB, 2015b).

\section{Figure 16. Small bank loans are relatively expensive}

Percentage points, average between December 2014 and November $2015^{1}$

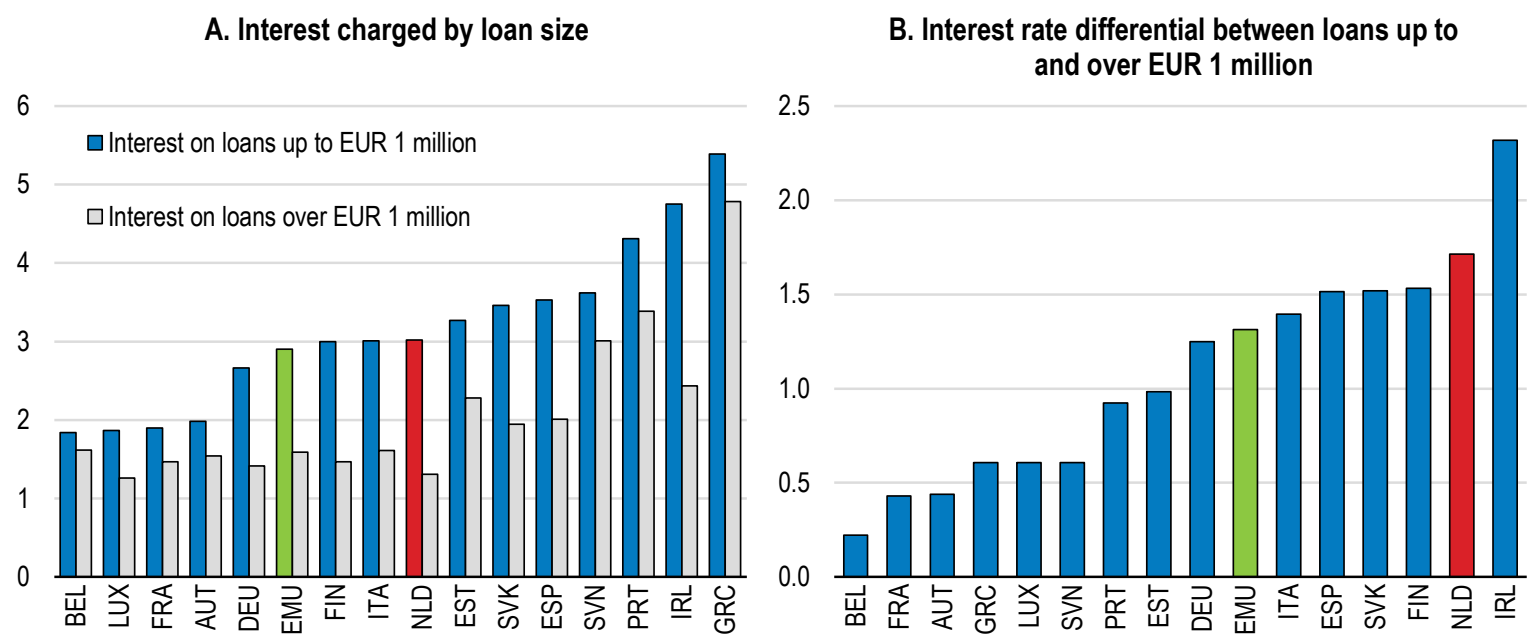

1. At floating rate and up to 1 year initial rate fixation. EMU: Euro area.

Source: ECB (2016), "Monetary and Financial Statistics: Bank Interest Rates Statistics", Statistical Data Warehouse, European Central Bank, February.

Competition in the market for retail loans can be stimulated by streamlining the procedure to obtain a banking licence. Potential entrants to the Dutch banking market indicate that the procedure is long, while ambiguity regarding some conditions contributes to the uncertainty of the application's outcome (ACM, 2014). A review of the procedure would indicate if improvements are possible without loosening the safeguards that the licence procedure currently provides.

Supporting SMEs to broaden their search for bank loans would also stimulate competition in retail lending. Almost $70 \%$ of the SMEs needing external finance only apply for a loan at their own bank, and $16 \%$ only ask their own bank and a single other bank (GfK, 2014). Increasing information regarding the supply, criteria and costs would lower search costs for SMEs. In addition, establishing the portability of bank account numbers, as was the case in the years before the introduction of IBAN numbers, would stimulate SMEs to switch banks by reducing administrational barriers (ACM, 2015).

Establishing a credit register would help lenders to assess the creditworthiness of SMEs. Estimating the creditworthiness of small firms is particularly difficult and costly, and the related uncertainty drives up interest rates and tightens lending conditions. A credit register for companies, similar to the one that already exists for individuals, would lower these costs by disseminating needed information to all lenders (SER, 2014), and it exists in most European countries (Rothemund and Gerhardt, 2011). The government 
has a project to allow company information obtained through the Standard Business Reporting to be used for loan applications. However, it is not fully clear that the Reporting data will allow the creation of a credit register, and the authorities should look into the feasibility of this approach with a view to creating a proper credit register.

\section{Encouraging market-based financing for SMEs}

Deepening non-bank financing would support companies in accessing financing suitable to their needs (OECD, 2014a). Bank loans generate moderate returns for lenders and are therefore most appropriate for low-risk lending related to sustaining ordinary activity and short-term needs of SMEs (OECD, 2013c). Financing innovative start-ups, young firms and SMEs with growth ambitions typically involves higher risks, due to a lack of collateral, cash flow and track record. For other investments, financial returns might be too uncertain or the required maturities too long. Alternative financing instruments with different risk-sharing mechanisms cover the entire risk/return spectre (OECD, 2013c; OECD, 2015h; Table 1) and are generally available in the Netherlands. However, for some types markets are underdeveloped which constrains especially new companies and those with high growth ambitions.

Table 1. A wide range of market-based financing complements bank lending for SMEs

\begin{tabular}{llll}
\hline Low Risk/ Return & Low Risk/ Return & Medium Risk/ Return & High Risk/ Return \\
\hline Asset-Based Finance & Alternative Debt & "Hybrid” Instruments & Equity Instruments \\
\hline Asset-based lending & Corporate Bonds & Subordinated Loans/Bonds & Private Equity \\
Factoring & Securitised Debt & Silent Participations & Venture Capital \\
Purchase Order Finance & Covered Bonds & Participating Loans & Business Angels \\
Warehouse Receipts & Private Placements & Profit Participation Rights & Specialised Platforms \\
Leasing & Crowdfunding (debt) & Convertible Bonds & for Public Listing of SMEs \\
& & Bonds with Warrants & Crowdfunding (equity) \\
& & Mezzanine Finance & \\
\hline
\end{tabular}

Source: OECD (2015), New approaches to SME and entrepreneurship finance: Broadening the range of instruments.

Market-based financing for larger SMEs is expanding. At NPEX, the SME stock exchange, companies can attract funding from investors starting from EUR 500000 either by issuing shares or bonds. Tradable assets have grown seven-fold since 2012, but the size remains modest at EUR 244 million. For midcaps with growth ambitions, private placements are increasingly becoming an alternative source of medium- and long-term financing. The market for private placements has slowly been taking off in recent years (DNB, 2015c). However, the market is too small to meet all financing needs and Dutch companies have issued USD 11 billion in private placements in the United States during the past five years. The development of a pan-European market is supported by the Capital Markets Union proposal of the European Commission and relatively favourably Solvency II capital requirements vis-à-vis investments with a lower creditworthiness.

The brighter economic prospects are also improving access to equity-based financing for start-ups and SMEs with growth ambitions. Investments by private equity and venture capital funds provided financing to a record number of 386 companies in 2014 (NVP, 2015). Total investments equalled EUR 3.1 billion, $30 \%$ higher than in 2014, although still below pre-crisis levels. Almost $60 \%$ of companies receiving financing were in an early stage, however, as amounts were small: seed, start-up and later stage venture financing accounted for less than 6\% of total investments and the amount was below the level in 2013. High public involvement remains necessary though, and almost $30 \%$ of the financing is brought by 
Regional Development Funds. Continuous efforts for establishing larger funds should make it easier to finance the growth phase of firms and attract larger (institutional) investors from home and abroad.

The authorities should continue to support the development of equity-based financing alternatives. The Dutch Venture Initiative of EUR 300 million, backed by the European Investment Fund and the Regional Participation Company of the province of Brabant and supported by the Ministry of Economic Affairs, is a useful addition to the venture capital ecosystem. In addition, the Growth Facility (Groeifaciliteit) of the government supports companies that need capital to finance for example an ambitious growth plan, a buy-out or expansion abroad by providing a 50\% guarantee on the risk-capital provided by investors. With the better economic prospects, the guarantees are quickly gaining in popularity: in the first half of 2015 EUR 43 million of guarantees were approved, which was already above the total for 2014.

New financing instruments such as crowdfunding and credit unions could help to close part of the finance gap for small firms when the market becomes more mature. Currently, they account for only $0.1 \%$ of business needs (Rabobank, 2015b), which is small in comparison to frontrunners such as the United Kingdom. However, the supply of these financing forms has grown rapidly in recent years. Crowdfunding, for example, has increased from EUR 2.5 million in 2011 to EUR 63 million in 2014 (Douw and Koren, 2015). Many initiatives stem from entrepreneurs, but some banks are also actively involved in the development of these new financing forms, which they see as complementary to traditional bank lending.

Dutch authorities are supportive of new financing instruments, but could do more to ensure sustainable market growth. The quick developments in financial technologies require regulation that limits risks for borrowers, lenders and the financial system - although these risks are often difficult to assess. Moreover, regulation should not unnecessarily inhibit growth of these new financing instruments (ACM, 2015). Regulations for credit unions are being simplified, so that they can attract deposits and loans for fixed-terms up to EUR 100 million without being considered and regulated as a bank. Regulations for crowd funding could also be improved (AFM, 2014), and planned legislation notably foresees an exemption to the ban on inducements, which should make business models more viable. Disclosure requirements could be eased, as a full prospectus is needed for projects with a value above EUR 2.5 million, although in many EU countries this is only required from the EU-wide minimum threshold of EUR 5million. Most legislation focuses on the protection of the lender, but at the same time, corporate borrowers have less legal protection than individuals, which in particular makes self-employed vulnerable. Better protection of corporate borrowers reduces the risk that insufficient due diligence from ambitious lenders leads to severe repayment problems that ultimately may harm the development of this nascent market (Turfboer, 2015).

Government programmes to support SME financing should better recognise the contribution new financing instruments can make, especially in the medium- to long-run. Current programmes mostly involve guarantees and funds, and many indirectly support bank lending. Favouring a specific financing form should be done with restraint (ACM, 2015). Extending government programmes to include new financing instruments, or formulating them in more general terms, would remove their current bias and increase the options for SMEs.

Increasing awareness among companies of alternative financing providers would benefit both. Since September 2015, a website supported by the Ministry of Economic Affairs helps entrepreneurs to understand the many available types of financing. Several private sector initiatives aim to help entrepreneurs in finding suitable financing by intermediating between companies and investors. In addition, they often help entrepreneurs to write a solid financing proposal. However, many companies are still only considering bank credit and cancel their investment plans when a loan is refused. Among this group, awareness of alternative financing sources could be raised by requiring banks to accompany a loan 
refusal by information on other financing options. For example, authorities in the United Kingdom plan to oblige major banks to refer a company to new online platforms when rejecting a loan application.

\section{Box 2. Recommendations to enhance private investment}

\section{Policies to promote adequate and financially sustainable investment in housing}

- Support the supply of rental housing by further limiting strict rent regulation in the private market.

- Monitor the provision of building plots by municipalities, especially for private rental housing. Review urban spatial planning regulation to identify obstacles for a higher residential density.

- Increase the financial sustainability of residential investment by accelerating the reduction of mortgage interest relief and lowering the maximum loan-to-value ratio of new mortgages significantly below $100 \%$.

- Increase public support for energy efficiency improvements, especially for owner-occupied housing and unregulated rentals, and make the replacement of old buildings by more efficient new constructions eligible as well.

- Improve insight in the developments of residential investment by providing data on its main components.

\section{Policies to support business investment}

- Step up efforts to strengthen innovation performance by increasing direct public support for R\&D.

- Continue to strengthen the diffusion of knowledge among the most innovative sectors and beyond, and further integrate SMEs and regions in the top sector approach.

- Support investment in ICT infrastructure by developing a strategic vision and increasing co-ordination among the stakeholders.

- Ensure stronger investment in renewable energy and energy efficiency by improving cost-effectiveness of existing instruments and possibly increasing their scale.

- Promote eco-innovation through increased support for R\&D, complementary demand side measures and partnerships with the private sector.

\section{Policies to support financing of business investment}

- Make equity investments more fiscally attractive, from the viewpoint of both investors and companies, to strengthen firms' balance sheets and to support both startups and companies with high growth ambitions.

- Increase competition in the market for SME loans by considering the creation of a credit register for companies, based on standard reporting if possible. In addition, increase publicly available information on lending terms and make bank account numbers portable.

- Support the sustainable development of new financing instruments through a balanced regulatory framework and their inclusion in public support programmes for SME financing. In addition, make referrals to alternative finance providers compulsory when banks reject a loan application.

- $\quad$ Adjust reporting obligations of banks to get a timely, reliable and publicly available insight of SME bank financing. 


\section{BIBLIOGRAPHY}

ACM (2015), "Concurrentie op de markt voor MKB-financiering" (Competetition in the market for SME financing), Monitor Financiële Sector, June 2015. Authoriteit Consument \& Markt (Authority Consumer \& Market).

ACM (2014), "Barrières voor toetreding tot de Nederlandse bancaire retailsector" (Barriers to entering the Dutch retail banking sector), Monitor Financiële Sector, June 2014. Authoriteit Consument \& Markt (Authority Consumer \& Market).

Adalet McGowan, M., D. Andrews and C. Criscuolo (2015), 'The Future of Productivity',OECD Publishing.

AFM (2014), "Crowdfunding - Naar een duurzame sector" (Crowdfunding - Towards a sustainable sector), Monitor Financiële Sector, June 2014. Authoriteit Financiële Markten (Authority Financial Markets).

Algemene Rekenkamer (2015), "Rapport stimulering van duurzame energieproductie (SDE+)" (Report on the renewable energy producers subsidy (SDE+)), Court of Audit, The Hague.

Andrews, D. and A. de Serres (2012), "Intangible Assets, Resource Allocation and Growth: A Framework for Analysis", OECD Economics Department Working Papers, No. 989, OECD Publishing, http://dx.doi.org/10.1787/5k92s63w14wb-en.

Andrews, D., A. Caldera Sánchez and Å. Johansson (2011), "Housing Markets and Structural Policies in OECD Countries", OECD Economics Department Working Papers, No. 836, OECD Publishing, http://dx.doi.org/10.1787/5kgk8t2k9vf3-en.

AWTI (2015), "Klaar voor de Toekomst” (Ready for the Future), Adviesraad voor wetenschap technologie en innovatie (Advisory council for science, technology and innovation).

Bank of England (2015), Inflation Report, August.

Buildings Performance Institute Europe (2015), Database, http://www.buildingsdata.eu/data-search (accessed on 19 November 2015).

Camps, M. (2015), “Kiezen voor kansen”(Seizing opportunities), Economisch Statistische Berichten, Vol. $100(4701)$.

CBS (2015a), Statline database, Statistics Netherlands. http://statline.cbs.nl/StatWeb/publication/?VW=T\&DM=SLNL\&PA=81647ned (accessed on 19 November 2015).

CBS (2015b), “Internationaliseringsmonitor" (Internationalisation monitor), Statistics Netherlands, February.

CBS (2015c), ICT and Economic growth. Statistics Netherlands.

Corrado, C., J. Haskel, C. Jona-Lasinio and M. Iommi (2013), "Innovation and intangible investment in Europe, Japan, and the United States", Oxford Review of Economic Policy, Vol. 29, No. 2. 
CPB (2015a), "Investment in the OECD: Pre- and Post-crisis Developments", CPB Communication, May 19, Netherlands Bureau for Economic Policy Analysis.

CPB (2015b), "De economische effecten van een verdure verlaging van de LTV-limiet"(The economic effects of an additional decrease of the LTV limit), Netherlands Bureau for Economic Policy Analysis.

CPB (2015c), "De Nederlandse financieringsstructuur in perspectief" (The Dutch financing structure in perspective), CPB Policy Brief 2015/14, Netherlands Bureau for Economic Policy Analysis.

CPB (2014), “A Study on R\&D Taks Incentives, Final Report”, Taxation papers working paper No. 52 2014, European Commission.

Criscuolo, C., P. Gal and C. Menon (2014), "The Dynamics of Employment Growth: New Evidence from 18 Countries", OECD Science, Technology and Industry Policy Papers, No. 14, http://dx.doi.org/10.1787/5jz417hj6hg6-en.

De Boer, R. and R. Bitetti (2014), "A Revival of the Private Rental Sector of the Housing Market?: Lessons from Germany, Finland, the Czech Republic and the Netherlands", OECD Economics Department Working Papers, No. 1170, OECD Publishing, http://dx.doi.org/10.1787/5jxv9f32j0zpen

Deloitte (2015), "Kantorentransformatiepotentie" (Office transformation potential), State of the State Woningmarkt.

DNB (2015a), "Effecten van een verdere verlaging van de LTV-limiet" (Effects of an additional decrease of the LTV limit), Occasional Studies, Vol. 13, no 2. De Nederlandsche Bank.

DNB (2015b), "Visie op de structuur van de Nederlandse banksector" (Vision on the structure of the Dutch banking sector), De Nederlandsche Bank.

DNB (2015c), “Investors offer alternative to bank lending”, DNBulletin. De Nederlandsche Bank.

Douw and Koren (2015), Crowdfunding in Nederland 2014: de cijfers (Crowdfunding in the Netherlands 2014: the numbers).

ECN (2015), "Nationale Energieverkenning" (Netherlands National Energy Outlook), Energieonderzoek Centrum Nederland (Energy research Centre of the Netherlands).

Ecofys (2015), Energetische renovatie van woningen, goed voor Nederland (Energetic renovations of dwellings, good for the Netherlands).

EIB (2015a), Investeren in Nederland (Investing in the Netherlands). Economisch Instituut voor de Bouw.

EIB (2015b), Infrastructuurmonitor - MIRT 2016 (Infrastructure Monitor - MIRT 2015). Economisch Instituut voor de Bouw.

Eijking, C. and J. de Jong (2015), "Afname publiek kapitaal biedt ruimte voor publieke investeringen” (Decrease of public capital provides space for public investment), Economisch Statistische Berichten, 100-4716.

EIO (2014), Eco-Innovation Scoreboard database, http://database.eco-innovation.eu/ (accessed 22 March 2015). 
Financieel Stabiliteitscomité (2015), "Conclusies van het Financieel Stabilietiscomité 12 mei 2015" (Conclusions from the Financial Stability Committee 12 May 2015).

GfK (2014). Survey on lending and current accounts for SMEs.

IMF (2015a), "Private Investment: What's the Holdup?", Chapter 4 in World Economic Outlook, April, International Monetary Fund, pp. 111-143.

IMF (2015b), "Kingdom of the Netherlands: Concluding Statement of the 2015 IMF Staff Visit", International Monetary Fund.

Koske, I., I. Wanner, R. Bitetti and O. Barbiero (2015), "The 2013 update of the OECD's database on product market regulation: Policy insights for OECD and non-OECD countries", OECD Economics Department Working Papers, No. 1200, OECD Publishing, http://dx.doi.org/10.1787/5js3f5d3n2vlen.

Lewis, C., N. Pain, J. Strasky and F. Menknya (2014), "Investment Gaps after the Crisis", OECD Economics Department Working Papers, No. 1168, OECD Publishing, http://dx.doi.org/10.1787/5jxvgg76vqg1-en.

Los, B., Timmer, M. en De Vries, G. (2014), "De concurrentiepositie van Nederland in mondiale waardeketens" ("De competitive stance of the Netherlands in global value chains"), Economisch Statistische Berichten, volume 99.

Ministerie van Binnenlandse Zaken en Koninkrijksrelaties (2013), Wonen in ongewone tijden (Living in unusual times), Ministry of Interior Affairs and Kingdom Relations.

Meijer, F., L. Itard and M. Sunikka-Blank (2010), “Comparing European residential building sticks: performance, renovation and policy opportunities", Building Research and Information, Vol. 37:5-6.

NVP (2015), Enterprising Capital: The Dutch private equity and venture capital market in 2014, Nederlandse Vereniging van Participatiemaatschappijen (Dutch Association of Participation Companies).

OECD (2016), OECD Economic Surveys: Netherlands 2016, OECD Publishing, http://dx.doi.org/10.1787/eco_surveys-nld-2016-en

OECD (2015a), "Lifting investment for higher sustainable growth", chapter 3 in OECD Economic Outlook June 2015, OECD publishing, http://dx.doi.org/10.1787/eco_outlook-v2015-1-en.

OECD (2015b), "Re-assessing the contribution of weak investment to the post-crisis slowdown in trend productivity and potential output growth", OECD Economics Department Working Papers, forthcoming.

OECD (2015c), OECD Environmental Performance Reviews: The Netherlands 2015, OECD Publishing, http://dx.doi.org/10.1787/9789264240056-en.

OECD (2015d), OECD Science, Technology and Industry Scoreboard 2015: Innovation for growth and society, OECD Publishing, http://dx.doi.org/10.1787/sti_scoreboard-2015-en.

OECD (2015e), The Innovation Imperative: Contributing to Productivity, Growth and Well-Being, OECD Publishing, http://dx.doi.org/10.1787/9789264239814-en. 
OECD (2015f), OECD Broadband Portal database.

http://www.oecd.org/sti/broadband/oecdbroadbandportal.htm (accessed on 15 December 2015).

OECD (2015g), Entrepreneurship at a glance 2015, OECD Publishing, http://dx.doi.org/10.1787/entrepreneur_aag-2015-en.

OECD (2015h), New approaches to SME and entrepreneurship finance: Broadening the range of instruments, OECD Publishing, http://dx.doi.org/10.1787/9789264240957-en.

OECD (2014a), OECD Economic Surveys: Netherlands 2014, OECD Publishing, http://dx.doi.org/10.1787/eco_surveys-nld-2014-en.

OECD (2014b), "Growth prospects and fiscal requirements over the long term", chapter 4 in $O E C D$ Economic Outlook May 2014, OECD publishing, http://dx.doi.org/10.1787/eco_outlook-v2014-1-en.

OECD (2014c), "Household debt", in OECD Factbook 2014: Economic, Environmental and Social Statistics, OECD Publishing, http://dx.doi.org/10.1787/factbook-2014-en.

OECD (2014d), OECD Reviews of Innovation Policy: Netherlands 2014, OECD Publishing, http://dx.doi.org/10.1787/9789264213159-en.

OECD (2014e), OECD Territorial Reviews: Netherlands 2014, OECD Publishing, http://dx.doi.org/10.1787/9789264209527-en.

OECD (2014f), OECD Science, Technology and Industry Outlook 2014, OECD Publishing, http://dx.doi.org/10.1787/sti_outlook-2014-en.

OECD (2013a), Pensions at a Glance 2013: OECD and G20 Indicators, OECD Publishing, http://dx.doi.org/10.1787/pension_glance-2013-en.

OECD (2013b), OECD Science, Technology and industry Scoreboard 2013: Innovation for Growth, OECD Publishing, http://dx.doi.org/10.1787/sti_scoreboard-2013-en.

OECD (2013c), Alternative Financing Instruments for SMEs and entrepreneurs: The case of Mezzanine Finance, OECD Publishing.

OECD (2010), OECD Economic Surveys: Netherlands 2010, OECD Publishing, http://dx.doi.org/10.1787/eco_surveys-nld-2010-en.

Panteia (2015), Financieringsmonitor 2015-1 Onderzoek naar de financiering van het Nederlandse bedrijfsleven (Financing monitor 2015-1: Analysis of Dutch private sector financing), Zoetermeer.

Panteia (2014), Entrepreneurship in the Netherlands, Zoetermeer.

PBL (2011), "Environmentally Harmful Subsidies", Planbureau voor the leefomgeving (Netherlands Environmental Assessment Agency), The Hague.

Rabobank (2015a), "Nederlandse woningmarkt: langzaam maar zeker meer huizen boven water" (Dutch housing market: more and more houses 'above water'), Economisch commentaar.

Rabobank (2015b), Alternatieve financiering voor het MKB: een update (Alternative financing for SMEs: an update). 
ECO/WKP(2016)29

RLI (2015), Wonen in verandering (Living in change), Raad voor de leefomgeving en infrastructuur (Council for the environment and infrastructure).

Rothemund, M. and M. Gerhardt (2011), The European Credit Information Landscape, European Credit Research Institute Industry Survey.

Rutte, M. (2015), Koning Willem I lezing (King William I speech).

SER (2014), Expanding and Increasing SME Financing, Sociaal-Economische Raad (Social Economic Council).

StartupDelta (2015), Brief aan de fractievoorzitters in de Tweede Kamer (Letter to the party leaders in the Lower House).

Transparency International (2014), Corruption Perceptions Index 2014.

Turfboer, N. (2015), “Alternative kredietverlener aan mkb heeft geen zorgplicht" (Alternative provider of SME credit does not have duty of care), in Follow the Money, 18-06-2015.

Van Steen, J. (2014), “Total Investment in Research and Innovation (TWIN) 2012-2018”, Facts \& Figures, Rathenau Institute, The Hague.

WEF (2015), The Global Competitiveness Report 2015-2016, World Economic Forum.

World Bank (2015), Doing Business 2016 - Measuring Regulatory Quality and Efficiency, Washington, DC. 